\title{
Analyzing the investment effects of forest rights devolution in Nepal's community-managed forest enterprises
}

Anukram Adhikary

Nayna Jhaveri

Rahul Karki

Naya Sharma Paudel 

Working Paper 254

\title{
Analyzing the investment effects of forest rights devolution in Nepal's community-managed forest enterprises
}

\author{
Anukram Adhikary \\ ForestAction Nepal \\ Nayna Jhaveri \\ Independent Researcher on Forest Tenure and Governance \\ Rahul Karki \\ ForestAction Nepal \\ Naya Sharma Paudel \\ ForestAction Nepal
}


Working Paper 254

(c) 2019 Center for International Forestry Research

(c) (i) Content in this publication is licensed under a Creative Commons Attribution 4.0 International (CC BY 4.0), http://creativecommons.org/licenses/by/4.0/

DOI: $10.17528 /$ cifor/007445

Adhikary A, Jhaveri N, Karki R, and Paudel NS. 2019. Analyzing the investment effects of forest rights devolution in Nepal's community-managed forest enterprises. Working Paper 254. Bogor, Indonesia: CIFOR.

\section{CIFOR}

Jl. CIFOR, Situ Gede

Bogor Barat 16115

Indonesia

$\mathrm{T}+62(251) 8622-622$

F +62 (251) 8622-100

E cifor@cgiar.org

\section{cifor.org}

We would like to thank all funding partners who supported this research through their contributions to the CGIAR Fund. For a full list of the 'CGIAR Fund' funding partners please see: http://www.cgiar.org/our-funders/

Any views expressed in this publication are those of the authors. They do not necessarily represent the views of CIFOR, the editors, the authors' institutions, the financial sponsors or the reviewers. 


\section{Contents}

Abbreviations $\quad$ v

Acknowledgements $\quad$ vi

Executive Summary vii

1 Introduction 1

2 Methods 3

3 Investment dynamics and potential of community-managed forest enterprises 6

4 Devolution of forest rights 9

5 Emergence and growth of community-managed forest enterprises 11

6 Regulatory frameworks governing community-managed forest enterprises 17

$\begin{array}{lll}6.1 & \text { Institutional modalities of community-managed forest enterprises } & 17\end{array}$

6.2 Government institutional arrangements for service delivery 20

$\begin{array}{lll}6.3 & \text { Distance-related rule } & 21\end{array}$

6.4 Transportation and export promotion $\quad 22$

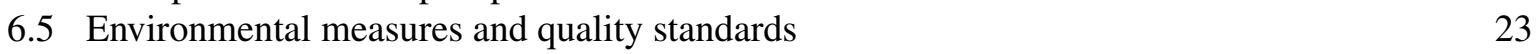

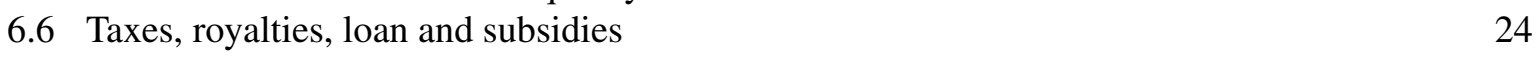

7 Non-regulatory context for community-managed forest enterprises 26

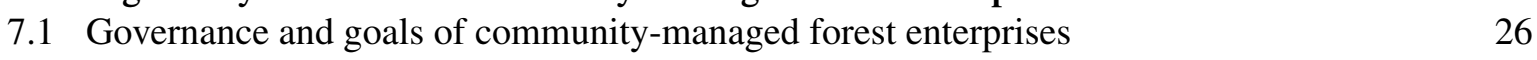

7.2 Role of Federation of Community Forestry Users, Nepal 29

$\begin{array}{lll}7.3 & \text { Raw material availability } & 30\end{array}$

$\begin{array}{lll}7.4 & \text { Skilled human resources } & 31\end{array}$

7.5 Access to financing 31

7.6 Entrepreneurial culture: Donors, business planning, development and profitability 32

$\begin{array}{lll}7.7 & \text { Technology } & 33\end{array}$

$\begin{array}{ll}7.8 \text { Advertising, branding and certification } & 34\end{array}$

8 Investment effects of community-managed forestry enterprises as social firms 36

9 Conclusion: Community-managed enterprises for prosperity 39

$\begin{array}{ll}\text { References } & 41\end{array}$ 


\section{List of figures and tables}

\section{Figure}

1 Location of the 12 CFE study sites

\section{Tables}

1 Key characteristics of the 12 CFEs under study 4

2 Differentiating enabling and asset investments in locally controlled forestry 8

3 Policies and laws regulating CFEs in Nepal 13

4 CFE modalities in NepalNotes:

5 Distance-related rules for forest-based enterprises 22

6 IEE/EIA requirement in Nepal's forestry sector 24 


\section{Abbreviations}

\begin{tabular}{ll} 
ANSAB & Asia Network for Sustainable Agriculture and Bioresources \\
BZ & Buffer Zone \\
BZCF & Buffer Zone Community Forestry \\
BZUG & Buffer Zone User Group \\
CBFM & Community-Based Forestry Management \\
CF & Community Forestry \\
CFE & Community-Managed Forest Enterprise \\
CFUGs & Community Forest User Groups \\
CIFOR & Center for International Forestry Research \\
DCSI & Department of Cottage and Small Industries \\
DFO & District Forest Office \\
EIA & Environmental Impact Assessment \\
FECOFUN & Federation of Community Forestry Users, Nepal \\
FFPO & Forest and Farm Producer Organization \\
FNCCI & Federation of Nepalese Chamber of Commerce and Industry \\
FSC & Forest Stewardship Council \\
GoN & Government of Nepal \\
I/NGOs & International/Non-Governmental Organizations \\
IEE & Initial Environmental Evaluation \\
IUCN & International Union for Conservation of Nature \\
LCF & Locally Controlled Forestry \\
LHF & Leasehold Forestry \\
MAPs & Medicinal and Aromatic Plants \\
MEDEP & Micro-Enterprise Development Programme \\
MFE & Ministry of Forests and Environment \\
MSFP & Multi-Stakeholder Forestry Program \\
NGO & Non-Governmental Organization \\
NPR & Nepalese Rupee \\
NTFPs & Non-Timber Forest Products \\
OP & Operational Plan \\
SMFE & Small- and Medium-Scale Forest Enterprise \\
SSFE & Small-Scale Forest Enterprise \\
UG & User Group \\
VDC & Village Delopment Committee \\
\hline
\end{tabular}




\section{Acknowledgements}

Funding from the Consultative Group for International Agricultural Research (CGIAR) Collaborative Research Program on Policies, Institutions and Markets (PIM) and the Center for International Forestry Research (CIFOR) supported this work. 


\section{Executive Summary}

This study critically explores the investment effects of forest rights devolution in Nepal's communitymanaged forest enterprises (CFEs). Forest rights devolution, starting from the late 1980s, opened the door to fundamental changes in the scale and structure of forest governance. Local-level user groups (UGs) for different types of community-based forest management (CBFM) were created, with community forestry (CF) receiving priority support from the government's forestry ministry. Under the 1993 Forest Act and 1995 Forest Regulations, community forestry user groups (CFUGs) were recognized as self-governing, independent, autonomous, perpetual and corporate institutions. Taking advantage of these devolved and secure tenure arrangements, CFUGs began to quickly form across the country, crafting their own local governance institutions. Once forests began to regenerate and meet subsistence needs, CFUGs and other types of UGs, such as those in buffer zone community forests, started to form CFEs to achieve further livelihood, social equity and income generation gains. CFEs were grafted onto the existing community-based governance institutions. Over this nearly 30 year period, many CFEs have been formed, some have survived, and new ones are being created each year. It has been a period of considerable, if unstable, growth for the CFE sector.

This study employs the concept of enabling and asset investments (Elson 2012) to analyze how UGs have established and managed CFEs. Based on primary data from interviews with 12 CFEs, and secondary data from published, government and gray literature, our research examined the investment effects on how UGs have structured CFE management, what the goals of CFEs have been, and how they negotiated the regulatory requirements, and non-regulatory conditions, in order to build their forest-based enterprises.

The high export demand for Nepal's non-timber forest products (NTFPs) from India (and elsewhere), especially the diversity of medicinal and aromatic plants (MAPs) from its forests led the Government of Nepal (GoN), from the late 1980s, to develop policy support to expand this trade. Later, in the late 2000s, trade and industrial policies began to reflect these same priorities recognizing the significant potential of MAPs to support Nepal's economic growth. As such, the majority of CFEs are engaged in harvesting and trading raw NTFPs. The combined effect of weak bargaining power, high transaction costs and inadequate processing facilities across the value chain means that traders buy these products from CFE harvesters at low prices. Beyond those supplying raw NTFPs, CFEs have focused on processing opportunities that permit value addition, such as essential oil extraction, handmade paper, fruit juices or wood-based products. The government, donors and I/NGOs have all contributed, enabling investments to help pilot CFEs through idea development, CFE registration, equipment purchases, staff training and building private sector partnerships.

The current set of legal frameworks available for registering a CFE, however, are not tailored to the conditions that prevail within CFEs: a collective governance arrangement with no formalized land ownership rights. As a result, UGs have to find ways of registering either as an enterprise (micro or small), cooperative or private limited company, each with their own tax requirements and incentives. Beyond this, the regulatory requirements for running a CFE are complex, involve responsibilities at the central and local level, are poorly harmonized and convoluted. Moreover, in the absence of adequate budgetary allocations, government service delivery has been weak and largely ineffective in terms of training and market development. The time, knowledge needs and cost involved in negotiating the regulatory bureaucracy can be beyond the capability of many CFEs. As a result, it is not surprising to find that most CFEs operate in an informal or unregulated manner, typically with the sanction of the District Forest Office based on the UG's operational plan. The outfall of these constraining factors has resulted in UG members recognizing that the tenure rights allocated to them, once thought to be very strong, are indeed much weaker in practice. 
Whether informal or formalized, UGs retain prime control over CFEs because they seek to protect their long-term investment in creating effective local governance and regenerating their local forest. As such, the vision and mission of the UG executive body holds primary influence when it comes to the CFE's social impact and entrepreneurial orientation. For many CFEs, improving social equity through employment opportunities as well as other forms of social welfare are prioritized above net profit-making. The prevailing structure of the relationship between UG and CFEs means that the subcommittees that run CFEs often do not hold much autonomous decision-making power in significant matters. Indeed, UG agendas are not abandoned when there is financial loss in CFE operations; UG funds or UG members may step up to cover such losses in order to keep the CFE afloat. In the absence of collateral for obtaining a bank loan, other sources of capital are sought, such as pooled financing from consortia of CFUGs. Sharing and pooling resources between UGs is a necessary way of building the economies of scale needed to startup and run a CFE. In order to attain their social welfare agenda, UG institutions are inherently unwilling to cede primary control over CFE governance to outside entities, such as the private sector, even though they could pursue some form of limited partnership or benefit-sharing arrangements. Only when there are difficult economic challenges do UGs begin to explore substantive private sector partnerships. There is an emerging trend whereby UGs have begun partnering with private sector entities. Some private sector companies are testing the waters, hoping to alter the risk variables through active engagement. Such partnership may take the form of shareholders within a CFE or the CFE may lease out their enterprise to the private entity for an annual sum.

Still, such a disheartening and unfavorable environment has broadly discouraged private sector investors from making asset investments in CFEs. Currently, they are at a crossroads, unsure whether they will abandon forest-based enterprise opportunities or commit to a business opportunity that could potentially be high value and low risk, provided the right set of changes in the enabling frameworks are created. There is room for optimism; in recent years, there has been an upswing in government focus on forest-based enterprises. In its 2015 Forest Sector Strategy and the 2015 Forest Policy, the government accorded greater priority to forest-based enterprises.

There is consensus among UG members, CFE managers, government officials, I/NGOs and the private sector that the full economic potential for improving rural prosperity and economic growth of the forestry sector has been far from realized in Nepal. We conclude that ultimately, CFEs, as a form of social impact investing within the forest sector, have much to learn from the global experience about how enabling and asset investments can be layered and sequenced in order to create multiple types of pathways to achieving social prosperity and profit-making. CFEs continue to hold the promise of changing the face of rural economies across large parts of the Himalayan landscape through effective forms of business governance and practices. 


\section{Introduction}

Since the 1990s, Nepal has seen substantial growth in community-managed forest enterprises (CFEs), particularly those focused on non-timber forest products (NTFPs), ${ }^{1}$ such as medicinal and aromatic plants (MAPs). CFEs can be defined as those forest industries managed by local communities for livelihood and profit that are engaged in the production, processing and trade of timber and wood products, as well as commercial NTFPs, and may also participate in markets for environmental services (see Molnar et al. 2017). In Nepal, CFEs are established by a range of community-based forest management (CBFM) institutions (such as community forestry user groups (CFUGs)). These are the result of an extensive devolution of forest rights that began in the late 1980s. CBFM institutions form the bedrock of CFEs and are largely found in community forestry $(\mathrm{CF})$, buffer zone community forestry (BZCF) to a lesser extent, and occasionally in leasehold forestry (LHF). They are one type of 'locally controlled forestry' (LCF), a global sector that has a strong potential to grow (Donovan et al. 2006; Mayers et al. 2016; Molnar et al. 2017). LCF enterprises hold considerable promise because they can address multiple goals such as income generation, poverty alleviation, social equity, climate change adaptation and mitigation, as well as support environmental and cultural stewardship (Macqueen 2008; Macqueen et al. 2018b). As social firms, their entrepreneurial spirit is typically a blended one that combines profit-making with social goals such as employment and other forms of social welfare support.

In Nepal, some older CFEs continue to operate and new CFEs are being registered every year. While there has been growing policy and legal support over time, there remain a spectrum of regulatory and non-regulatory barriers to CFE startup and operation (Subedi 1999, 2006; Kanel 2000; Subedi et al. 2014; Rai et al. 2016; Paudel et al. 2018). Most CFEs are involved with NTFPs, given the growing export-oriented demand, particularly from India. In contrast, extractive activities and trade in woodbased products has been strictly controlled by the government due to a conservation-oriented approach to forest management (Acharya and Acharya 2007), although that stance has recently started to soften.

The almost 30-year period from the early 1990s to the present day has seen many government-led programs and donor-supported initiatives working together with international and non-governmental organizations (I/NGOs), community forestry federations and the private sector to pilot diverse types of CFEs in geographically different parts of Nepal. In an incubatory sense, this period has been the first wave of CFE development. Grafting entrepreneurship onto community-based forms of forest governance involved many innovations as user groups (UGs) sought to craft ways of staying close to their social welfare and conservation mission even as they aimed to boost net profitability.

Recognizing that the natural resources they have regenerated in their forests can be leveraged to improve prosperity in a broader sense, CFEs have persisted in running their enterprises despite many obstacles. A number have started, only to close down in a few years. Some have survived the initial turbulence and are still functioning after 20 years. All in all, large numbers of CFEs remain unregulated and informal. As a country that is globally ranked 110 among 190 economies in the Ease of Doing Business Index, ${ }^{2}$ it is Nepal's entrepreneurial economy at large that faces numerous challenges.

1 NTFPs are all those natural resources available in forests other than timber, fuelwood and fodder. Examples include medicinal and aromatic plants (MAPs); bamboo and rattan; nuts, fruits, tubers and berries; grasses and leaves; resins; insects and insect providers; and wild animals and birds. Typically, though, NTFPs refer to plant products.

2 This index ranking is prepared annually by the World Bank. See: https://tradingeconomics.com/nepal/ease-of-doing-business 
Donors and I/NGOs have sought to diagnose the problems underlying CFE startup and growth within their pilot sites (Subedi et al. 2014; Acharya 2013; Rai et al. 2016; Rytkönen 2016; Lamsal et al. 2017; Sharma et al. 2017; Paudel et al. 2018). Findings from research on NTFP-oriented CFEs indicate that NTFP policy formation, implementation and field reality are poorly linked (Larsen et al. 2000; see also Kanel 2000). Specifically, in the Koshi Hills, CFEs in more accessible areas, closer to markets, and road transportation tend to continue operating, whereas those in remote areas are likely to close down (Rai et al. 2016). One of the main lessons that emerges from this research is that although the regulatory environment clearly has an effect on how CFEs operate, there still remains limited knowledge about how policies and laws actually affect the level of investment, associated benefits and therefore success of CFEs (Kunwar et al. 2009; Dhakal et al. 2018). In particular, understanding how regulatory structures play out within the local context is critical for designing targeted interventions to support CFE growth (Lamsal et al. 2017; see also Edwards 1996).

In light of these findings, this working paper specifically examines how the policy, legal and nonregulatory context affect investment dynamics within CFEs that have been the beneficiaries of substantial devolution of forest rights. The paper's analysis is based on original research among 12 selected CFEs to examine how CFEs craft the structure, governance and business operations of their entrepreneurial activity within the prevailing business environment. This analysis then serves to draw out the main challenges and gaps that need to be addressed to propel the CFE sector forward in its emergent second phase.

The document is organized into nine main sections. The section following this introduction sets out the methodology behind the research. The next three sections provide a literature review of the current global understanding of the potential of CFEs, an overview of forest rights devolution in Nepal, and a review of the emergence and growth of CFEs respectively. The paper then moves into an analysis of influential regulatory frameworks (section 6) and non-regulatory factors (section 7) before reviewing how they have affected investment dynamics within the current context (section 8). This section also sets out the key findings for supporting policy, legal and programmatic initiatives to enable the CFE sector to grow and mature. Section 9 provides a conclusion that assesses the potential of CFEs to contribute to rural prosperity and livelihoods in Nepal. 


\section{Methods}

The analysis presented in this working paper is based on both primary and secondary sources. As a primary source, the study draws upon the empirical findings of a study entitled "Forest Tenure Reform and Investment Outcomes: Evidence from Community Forest Enterprises in Nepal" that was undertaken by ForestAction Nepal and the Center for International Forestry Research (CIFOR) in 2016. In conducting this earlier study, a review of the published, government and gray literature on the following themes was carried out:

- current understanding of the factors driving interest in and growth of LCF and CFEs at the global scale;

- history and scope of forest rights devolution in Nepal;

- $\quad$ establishment and growth of CFEs in Nepal;

- relevant Nepal government policy and legal documents on forest-based enterprises.

This first step not only permitted the identification of key factors affecting CFE startup and growth, but it also guided the selection of experts for interviews as well as specific CFEs as case studies for detailed analysis. Following this, expert meetings were held with government officials, the Federation of Community Forestry Users, Nepal (FECOFUN), relevant I/NGOs, and the Federation of Forestbased Industry and Trade.

The selection of 12 CFEs as case studies sought to capture timber, NTFP and ecotourism enterprises in Nepal's major ecological areas. Three important geographical clusters were identified: the KavreDolakha-Sindhupalchowk-Ramechhap cluster, the Chitwan cluster and the Nawalparasi-Dang-Banke cluster. The first cluster represents the mountains and hills cluster that has carried out long periods of donor-supported activities covering timber and NTFP activity. The Chitwan cluster covers ecotourism enterprises in the Terai, and the Nawalparasi-Dang-Banke cluster represents timber and NTFP enterprises in the Terai (see Figure 1).

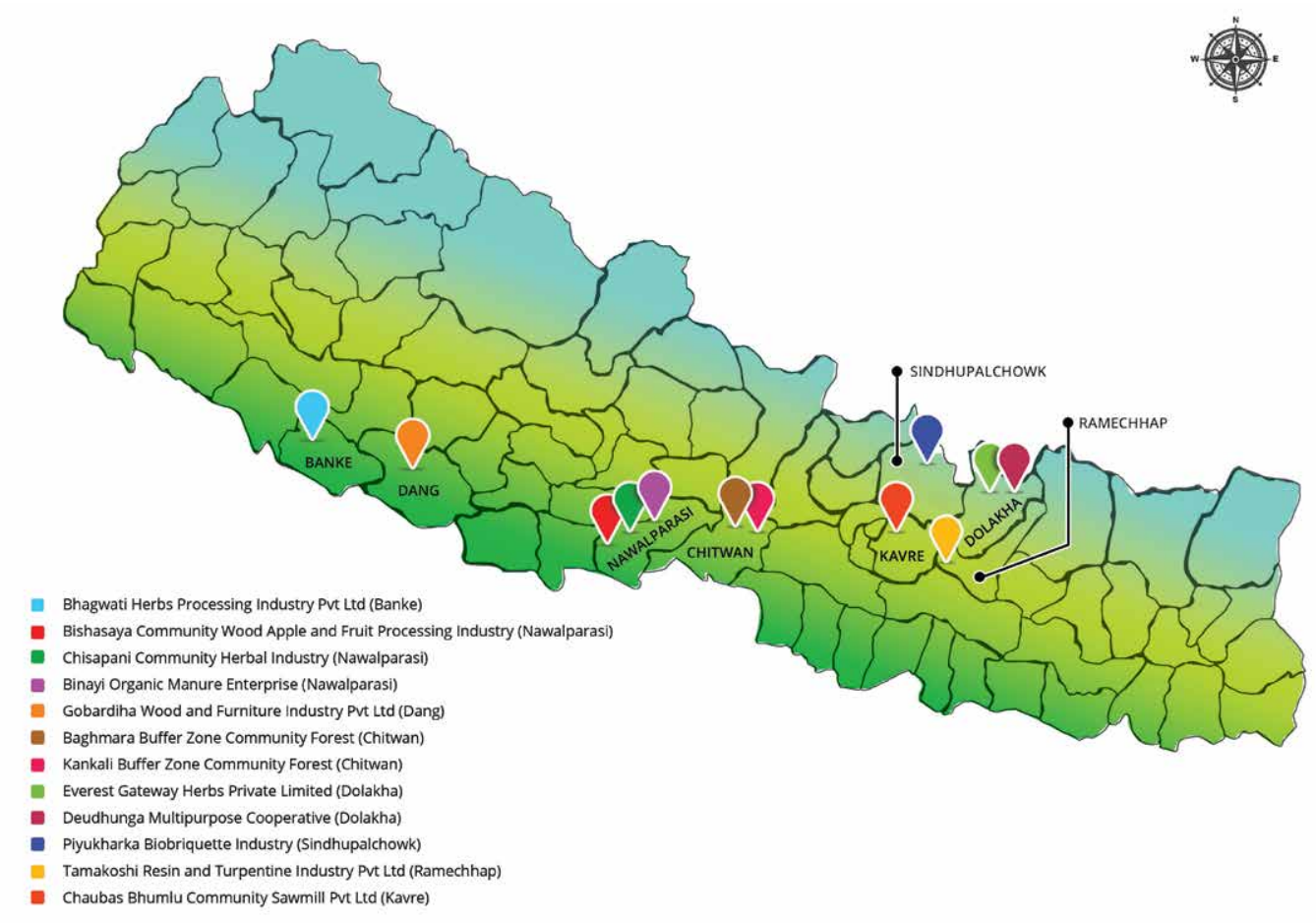

Figure 1. Location of the 12 CFE study sites 
Semi-structured interviews were carried out with the CFE managers and UG members (including disadvantaged members) together with document analysis (such as official documents, forest operational plans (OP) and meeting minutes) and observation during field visits. Table 1 sets out the key characteristics of the selected CFEs.

Table 1. Key characteristics of the 12 CFEs under study

\begin{tabular}{|c|c|c|c|c|c|c|}
\hline Enterprise & $\begin{array}{l}\text { Bhagwati } \\
\text { Herbs } \\
\text { Processing } \\
\text { Industry } \\
\text { Pvt Ltd }\end{array}$ & $\begin{array}{l}\text { Bishasaya } \\
\text { Community } \\
\text { Wood Apple } \\
\text { and Fruit } \\
\text { Processing } \\
\text { Industry } \\
\end{array}$ & $\begin{array}{c}\text { Chisapani } \\
\text { Community } \\
\text { Herbal } \\
\text { Industry }\end{array}$ & $\begin{array}{l}\text { Gobardiha } \\
\text { Wood and } \\
\text { Furniture } \\
\text { Industry Pvt } \\
\text { Ltd }\end{array}$ & $\begin{array}{c}\text { Baghmara } \\
\text { Buffer Zone } \\
\text { Community } \\
\text { Forest }\end{array}$ & $\begin{array}{c}\text { Kankali } \\
\text { Buffer } \\
\text { Zone } \\
\text { Community } \\
\text { Forest }\end{array}$ \\
\hline $\begin{array}{l}\text { Years in } \\
\text { operation }\end{array}$ & 11 & 7 & 7 & 6 & 18 & 11 \\
\hline $\begin{array}{l}\text { Number of } \\
\text { collaborating } \\
\text { CFUGs }\end{array}$ & 11 & 1 & 1 & 12 & 2 & 1 \\
\hline District & Banke & Nawalparasi & Nawalparasi & Dang & Chitwan & Chitwan \\
\hline Product & Essential oil & $\begin{array}{l}\text { Wood apple } \\
\text { (bael) juice }\end{array}$ & Essential oil & $\begin{array}{l}\text { Sawmilling of } \\
\text { CF timber }\end{array}$ & Tourism & Tourism \\
\hline Legal status & $\begin{array}{l}\text { Private } \\
\text { limited } \\
\text { company }\end{array}$ & $\begin{array}{l}\text { Cottage } \\
\text { industry }\end{array}$ & $\begin{array}{l}\text { No } \\
\text { registration }\end{array}$ & $\begin{array}{l}\text { Private } \\
\text { limited } \\
\text { company }\end{array}$ & $\begin{array}{l}\text { CFUG, no } \\
\text { registration } \\
\text { required by } \\
\text { law }\end{array}$ & $\begin{array}{l}\text { CFUG, no } \\
\text { registration } \\
\text { required by } \\
\text { law }\end{array}$ \\
\hline $\begin{array}{l}\text { Operational } \\
\text { modality }\end{array}$ & $\begin{array}{l}\text { CFUG } \\
\text { consortium } \\
\text { managed }\end{array}$ & $\begin{array}{l}\text { CFUG and } \\
\text { private sector } \\
\text { management }\end{array}$ & $\begin{array}{l}\text { CFUG } \\
\text { managed } \\
\text { with private } \\
\text { collaboration }\end{array}$ & $\begin{array}{l}\text { CFUG } \\
\text { consortium }\end{array}$ & $\begin{array}{l}\text { CFUG leased } \\
\text { to private }\end{array}$ & $\begin{array}{l}\text { CFUG } \\
\text { managed }\end{array}$ \\
\hline $\begin{array}{l}\text { Initiating } \\
\text { agency }\end{array}$ & NGO & NGO & $\mathrm{NGO/CFUG}$ & $\mathrm{NGO/CFUG}$ & CFUG & CFUG \\
\hline $\begin{array}{l}\text { Investment } \\
\text { capital }\end{array}$ & $\begin{array}{l}\text { NGO, } \\
\text { CFUG, } \\
\text { bank loan }\end{array}$ & $\begin{array}{l}\text { NGO, CFUG, } \\
\text { private }\end{array}$ & $\begin{array}{l}\text { NGO, CFUG, } \\
\text { private }\end{array}$ & CFUG & CFUG & CFUG \\
\hline Market outlet & $\begin{array}{l}\text { Assured } \\
\text { market }\end{array}$ & Self-marketing & $\begin{array}{l}\text { Community } \\
\text { members, } \\
\text { private firms }\end{array}$ & $\begin{array}{l}\text { Community } \\
\text { households }\end{array}$ & Private sector & $\begin{array}{l}\text { Individual } \\
\text { users }\end{array}$ \\
\hline Shareholders & CFUG & CFUG & $\begin{array}{l}\text { CFUG, } \\
\text { women's } \\
\text { group }\end{array}$ & $\begin{array}{l}\text { CFUG, CF } \\
\text { members }\end{array}$ & CFUG & CFUG \\
\hline $\begin{array}{l}\text { Capacity } \\
\text { utilization }\end{array}$ & $\begin{array}{l}\text { Full } \\
\text { capacity } \\
\text { during } \\
\text { harvesting } \\
\text { season (6 } \\
\text { months) }\end{array}$ & $\begin{array}{l}60 \% \\
\text { (insufficient } \\
\text { markets) }\end{array}$ & $\begin{array}{l}20 \% \\
\text { (insufficient } \\
\text { raw material) }\end{array}$ & $20 \%$ & Full capacity & Full capacity \\
\hline $\begin{array}{l}\text { Profit loss, } \\
\text { dividend }\end{array}$ & $\begin{array}{l}\text { Profit } \\
\text { (dividend } \\
\text { not } \\
\text { distributed) }\end{array}$ & $\begin{array}{l}\text { Loss (loss } \\
\text { compensated } \\
\text { for from CFUG } \\
\text { income) }\end{array}$ & $\begin{array}{l}\text { Profit (profit } \\
\text { kept in CF } \\
\text { fund) }\end{array}$ & $\begin{array}{l}\text { Profit } \\
\text { (dividend not } \\
\text { distributed) }\end{array}$ & $\begin{array}{l}\text { Profit (profit } \\
\text { kept in CF } \\
\text { fund) }\end{array}$ & $\begin{array}{l}\text { Profit (profit } \\
\text { kept in CF } \\
\text { fund) }\end{array}$ \\
\hline $\begin{array}{l}\text { Major } \\
\text { institutional } \\
\text { issue(s) }\end{array}$ & $\begin{array}{l}\text { Not legally } \\
\text { registered } \\
\text { due to } \\
\text { distance } \\
\text { rule }\end{array}$ & $\begin{array}{l}\text { No major } \\
\text { issue, seeking } \\
\text { additional } \\
\text { market support } \\
\text { and tax waiver }\end{array}$ & $\begin{array}{l}\text { Not legally } \\
\text { registered } \\
\text { due to } \\
\text { distance rule; } \\
\text { infrastructure } \\
\text { rule }\end{array}$ & $\begin{array}{l}\text { Not legally } \\
\text { registered due } \\
\text { to distance } \\
\text { rule; difficult } \\
\text { to get sawing } \\
\text { permission }\end{array}$ & $\begin{array}{l}\text { No } \\
\text { permission } \\
\text { to construct } \\
\text { infrastructure }\end{array}$ & $\begin{array}{l}\text { No permis- } \\
\text { sion to } \\
\text { construct } \\
\text { infrastruc- } \\
\text { ture }\end{array}$ \\
\hline
\end{tabular}




\begin{tabular}{|c|c|c|c|c|c|c|}
\hline Enterprise & $\begin{array}{l}\text { Deudhunga } \\
\text { Multipurpose } \\
\text { Cooperative }\end{array}$ & $\begin{array}{c}\text { Everest } \\
\text { Gateway } \\
\text { Herbs Pvt } \\
\text { Ltd }\end{array}$ & $\begin{array}{c}\text { Piyukharka } \\
\text { Biobriquette } \\
\text { Industry }\end{array}$ & $\begin{array}{c}\text { Tamakoshi } \\
\text { Resin and } \\
\text { Turpentine } \\
\text { Industry Pvt } \\
\text { Ltd }\end{array}$ & $\begin{array}{c}\text { Chaubas } \\
\text { Bhumlu } \\
\text { Community } \\
\text { Sawmill Pvt } \\
\text { Ltd }\end{array}$ & $\begin{array}{c}\text { Binayi } \\
\text { Organic } \\
\text { Manure } \\
\text { Enterprise }\end{array}$ \\
\hline $\begin{array}{l}\text { Years in } \\
\text { operation }\end{array}$ & 17 & 12 & 5 & 7 & 20 & 1 \\
\hline $\begin{array}{l}\text { Number of } \\
\text { collaborating } \\
\text { CFUGs }\end{array}$ & 5 & 4 & 6 & 13 & 4 & 1 \\
\hline District & Dolakha & Dolakha & Dolakha & Ramechhap & Kavre & Nawalparasi \\
\hline Product & Essential oil & $\begin{array}{l}\text { Handmade } \\
\text { paper }\end{array}$ & $\begin{array}{l}\text { Biomass } \\
\text { briquettes }\end{array}$ & $\begin{array}{l}\text { Resin } \\
\text { turpentine } \\
\text { extraction and } \\
\text { processing }\end{array}$ & $\begin{array}{l}\text { Sawmilling } \\
\text { of CF timber }\end{array}$ & $\begin{array}{l}\text { Organic } \\
\text { manure }\end{array}$ \\
\hline Legal status & No registration & $\begin{array}{l}\text { Private limited } \\
\text { company }\end{array}$ & $\begin{array}{l}\text { Cottage } \\
\text { industry }\end{array}$ & $\begin{array}{l}\text { Private limited } \\
\text { company }\end{array}$ & $\begin{array}{l}\text { Private limited } \\
\text { company }\end{array}$ & $\begin{array}{l}\text { No legal } \\
\text { status }\end{array}$ \\
\hline $\begin{array}{l}\text { Operational } \\
\text { modality }\end{array}$ & $\begin{array}{l}\text { CFUG } \\
\text { consortium } \\
\text { leased to private }\end{array}$ & $\begin{array}{l}\text { CFUG } \\
\text { managed } \\
\text { with private } \\
\text { collaboration }\end{array}$ & $\begin{array}{l}\text { CFUG } \\
\text { managed } \\
\text { with private } \\
\text { collaboration }\end{array}$ & $\begin{array}{l}\text { CFUG with } \\
\text { licensing to } \\
\text { private sector }\end{array}$ & $\begin{array}{l}\text { CFUG } \\
\text { managed }\end{array}$ & $\begin{array}{l}\text { CFUG } \\
\text { managed }\end{array}$ \\
\hline $\begin{array}{l}\text { Initiating } \\
\text { agency }\end{array}$ & INGO, NGO & INGO, NGO & NGO & $\begin{array}{l}\text { NGO/ } \\
\text { community }\end{array}$ & INGO & $\begin{array}{l}\text { Government } \\
\text { project: Multi } \\
\text { Stakeholder } \\
\text { Forestry } \\
\text { Programme } \\
\text { (MSFP) }\end{array}$ \\
\hline $\begin{array}{l}\text { Investment } \\
\text { capital }\end{array}$ & $\begin{array}{l}\text { INGO, CFUG, } \\
\text { private }\end{array}$ & $\begin{array}{l}\text { INGO, } \\
\text { CFUG, CF } \\
\text { members }\end{array}$ & $\begin{array}{l}\text { INGO, } \\
\text { CFUG, CF } \\
\text { members }\end{array}$ & $\begin{array}{l}\text { NGO, CFUG, } \\
\text { CF members }\end{array}$ & NGO, CFUG & DFO, MSFP \\
\hline $\begin{array}{l}\text { Market } \\
\text { outlet }\end{array}$ & $\begin{array}{l}\text { Assured private } \\
\text { sector/promoted } \\
\text { market }\end{array}$ & $\begin{array}{l}\text { Assured } \\
\text { private sector/ } \\
\text { promoted } \\
\text { market }\end{array}$ & $\begin{array}{l}\text { Assured } \\
\text { private sector/ } \\
\text { promoted } \\
\text { market }\end{array}$ & $\begin{array}{l}\text { Assured } \\
\text { private sector } \\
\text { market }\end{array}$ & $\begin{array}{l}\text { Self- } \\
\text { marketing }\end{array}$ & $\begin{array}{l}\text { Self- } \\
\text { marketing }\end{array}$ \\
\hline Shareholders & $\begin{array}{l}\text { CFUG, } \mathrm{CF} \\
\text { members, private }\end{array}$ & $\begin{array}{l}\text { CFUG, CF } \\
\text { members, } \\
\text { private }\end{array}$ & $\begin{array}{l}\text { CFUG, CF } \\
\text { members }\end{array}$ & $\begin{array}{l}\text { CFUG, CF } \\
\text { members }\end{array}$ & CFUG & CFUG \\
\hline $\begin{array}{l}\text { Capacity } \\
\text { utilization } \\
(\%)\end{array}$ & $\begin{array}{l}20 \text { percent } \\
\text { (degraded } \\
\text { resource) }\end{array}$ & $\begin{array}{l}\text { Operation } \\
\text { stopped due } \\
\text { to building } \\
\text { collapse }\end{array}$ & $\begin{array}{l}\text { Full capacity } \\
\text { (operation } \\
\text { stopped due } \\
\text { to building } \\
\text { collapse in } \\
\text { previous year) }\end{array}$ & $\begin{array}{l}\text { Full capacity } \\
\text { (collection } \\
\text { at full } \\
\text { capacity but } \\
\text { processing is } \\
\text { not permitted } \\
\text { due to } \\
\text { distance rule) }\end{array}$ & 25 percent & $\begin{array}{l}\text { Undeter- } \\
\text { mined - first } \\
\text { batch recent- } \\
\text { ly prepared }\end{array}$ \\
\hline $\begin{array}{l}\text { Profit loss, } \\
\text { dividend }\end{array}$ & $\begin{array}{l}\text { Profit (profit } \\
\text { kept by private } \\
\text { individuals, } \mathrm{CF} \\
\text { receives royalty) }\end{array}$ & $\begin{array}{l}\text { Operations } \\
\text { stopped due } \\
\text { to earthquake, } \\
\text { otherwise } \\
\text { previously } \\
\text { profitable }\end{array}$ & $\begin{array}{l}\text { Profit (benefit } \\
\text { shared two } \\
\text { years ago, } \\
\text { operation } \\
\text { disrupted by } \\
\text { earthquake) }\end{array}$ & $\begin{array}{l}\text { Profit } \\
\text { (dividend } \\
\text { distributed as } \\
\text { shares) }\end{array}$ & $\begin{array}{l}\text { Loss and un- } \\
\text { operational, } \\
\text { restarting } \\
\text { under new } \\
\text { operational } \\
\text { modality }\end{array}$ & $\begin{array}{l}\text { Just began } \\
\text { operations, } \\
\text { too early } \\
\text { to tell if } \\
\text { profitable }\end{array}$ \\
\hline $\begin{array}{l}\text { Major } \\
\text { institutional } \\
\text { issue(s) }\end{array}$ & $\begin{array}{l}\text { Not legally } \\
\text { registered due } \\
\text { to distance rule }\end{array}$ & $\begin{array}{l}\text { No major } \\
\text { issues; minor } \\
\text { interruption } \\
\text { in operation } \\
\text { during } \\
\text { delivery }\end{array}$ & $\begin{array}{l}\text { No major } \\
\text { issue, although } \\
\text { distance rule } \\
\text { still an issue } \\
\text { for full fledged } \\
\text { growth }\end{array}$ & $\begin{array}{l}\text { Not legally } \\
\text { registered for } \\
\text { processing } \\
\text { due to } \\
\text { distance rule }\end{array}$ & $\begin{array}{l}\text { Difficulties } \\
\text { getting } \\
\text { harvest } \\
\text { provision } \\
\text { from DFO }\end{array}$ & $\begin{array}{l}\text { No major } \\
\text { issues so far }\end{array}$ \\
\hline
\end{tabular}

Source: Adapted from Sharma et al. (in press) 


\title{
3 Investment dynamics and potential of community-managed forest enterprises
}

\begin{abstract}
According to a growing global consensus that has been building from the early 2000s, LCF has the potential to substantially expand (Donovan et al. 2006; Mayers et al. 2016; Molnar et al. 2017). Typically, LCF is composed of enterprises that produce a range of timber and non-timber commodities from forested areas. LCF, as a term agreed by international alliances of family, community and indigenous people's forestry, comprises those forest enterprises where forest owner families and communities have local rights to make decisions on commercial forest management and land use, with secure tenure rights, freedom of association and access to markets and technology (Macqueen et al. 2018b). LCF can include various types of organizations, such as CFEs, forest and farm producer organizations (FFPOs), and small- and medium-scale forest enterprises (SMFEs). Among these, CFEs can be defined as enterprises that have ownership or tenure rights over collectively held resources in which the community UG is the principal investment partner (Gynch et al. 2019). The creation of community-based forestry UGs is an outcome of forest rights devolution.
\end{abstract}

The promise of LCF is very compelling because it could address multiple goals, such as income generation, ${ }^{3}$ poverty alleviation, social equity, climate change adaptation and mitigation, as well as environmental and cultural stewardship writ large (Macqueen 2008; Macqueen et al. 2018b). This section reviews whether and how the research on the factors that enable LCF, in particular CFEs, to take root and prosper analyzes how forest rights devolution affects investment dynamics in CFEs. Among the LCFs, CFEs are distinctive because their management structure is grafted onto community forms of governance and can be considered one type of corporate private property, or a middle pathway between private and public sector production (Antinori and Bray 2005). Besides Nepal, CFEs are found in a cluster of countries, such as Brazil, India, Guatemala, Mexico and Uganda.

Determining the aggregate scale of locally controlled forest-linked production and investment is no easy task, even though anecdotal evidence suggests its existence is of a very substantial scale (Mayers et al. 2016). One estimate puts the number of individual forest-linked producers, small-scale FFPOs, and small enterprises at 1 billion on the global scale (Mayers et al. 2016). Notably, forest producer organizations contribute to a broader spectrum of social and environmental values than are normally used to assess business performance, because of their social principles (Berkes and Davidson-Hunt 2010; Macqueen et al. 2018b; Tirivayi et al. 2018). The small scale of LCF results in management that is sensitive to local conditions, can be attentive to sustainability of resources, operates in a flexible manner and can be oriented toward better social inclusiveness. However, its small scale also results in weaknesses, such as difficulty in obtaining economies of scale, investing in new technology, obtaining financial credit, and weak business management and marketing capabilities.

There has recently been an increase in research seeking to identify the conditions for growth and success within varied types of LCF (Macqueen 2008; Macqueen et al. 2014; Pasiecznik et al. 2015). One major finding that underlies the difficulties that LCF faces is the lack of connectedness (Macqueen 2008). The paucity of neutral organizations (such as FFPOs) to incubate, link and aggregate the activities of individual enterprises has meant that there is insufficient growth momentum. A recent study of SMFEs identified a set of 12 emergent critical success factors, including external factors:

3 In some countries, SMFEs provide some 80-90\% employment within the forest sector (PROFOR 2018). Recent economic analysis of smallholders (including crop, timber and non-timber producers) indicates its value stands anywhere between $\$ 869$ billion and $\$ 1.29$ trillion (Verdone 2018). With further multiplier effects and non-market values specific to smallholder production, these figures could be even ten-fold greater. 
(a) enabling business environments, (b) macroeconomic setting, (c) regulatory frameworks, (d) forest law enforcement, (e) tenure and ownership rights, (f) management and land-use planning rights, (g) markets, (h) natural capital, and internal factors, (i) financial capital, (j) forest management capacities, (k) business management capacities, (l) organizational capacities, and (m) clustering ${ }^{4}$ (Badini et al. 2018). A similar set of internal and external factors have been identified in other studies specifically examining CFE growth (Stoian et al. 2009; Molnar et al. 2017). Some have examined particular dimensions of LCF such as risk management (Bolin et al. 2017), access to appropriate finance (FAO 2005, Macqueen et al. 2018a), business incubation approaches involving larger FFPOs (Macqueen and Bolin 2018; Macqueen 2019) and gender, collective action and women's entrepreneurship (Bolin 2018).

While these factors are patently important in achieving success, it is the LCF governance entity that is the institution through which these factors exert their effect. Research on the successful case of Mexican timber-oriented CFEs that emerged in the 1970s pointed to the importance of examining the CFE governance system. It indicated that CFEs had distinctive institutional characteristics that were not easily explained by the theory of the firm (Antinori and Bray 2005; Bray 2010). They had "unique management tensions, varieties of possible institutional arrangements governing stocks and flows of the natural resource, and may have special importance in delivering both economic equity and environmental protection" (Antinori and Bray 2005, 1529). CFEs have diverse types of ownership, organization and operation (Berkes and Davidson-Hunt 2010). The distinctiveness of CFE organization lent itself to being called a 'social firm' (Antinori and Bray 2005, 1531). Given that generalizations about CFE development and trends are hard to make, due to the particularity of forest rights devolution processes, as well as the geographical and value-based variability of production, this research points to the need for detailed institutional analysis of CFE governance. As with CF (Baynes et al. 2015), there is a multidimensional nature to 'success' in CFEs.

Our research builds upon this analysis by examining how regulatory and non-regulatory factors (including CFE governance) affect investment dynamics within the specific context of forest rights devolution in Nepal. How does the grafting of CFEs onto community forms of forest governance influence investment dynamics? Which entities and what types of investments have been made in CFEs and to what effect? What types of activities are investments supporting? In this paper, for analytical purposes, investment covers both enabling and asset investment (Elson 2012). As Dominic Elson (2012) has emphasized, it is necessary to layer both enabling and asset investments in order to generate both public goods, as well as create private assets, within LCF (see Table 2). Enabling investments are those that provide the foundations for commercial viability and social impact, even if they do not produce any evident direct financial return. These can include support for institutional development and governance, technological knowledge, market services, infrastructure and quality control. Asset investments are those that seek a financial return and can include some activities as investment in fixed or working capital (for a range of activities), financial services or product purchase.

Indeed, such investments, as in the case of CFEs, can typically be seen as social impact investing where there is a balance (along a spectrum) between social and environmental returns of various kinds and profit-making. In social impact investing, focusing on careful institutional preparation, gradual buildup of investment worthiness and sustainable natural resource management are critical dimensions of launching on the path to success over time (Gynch et al. 2019). Understanding the details of how these dynamics can be encouraged to sequentially develop prepares the ground for successful social impact investing in CFEs.

4 Clustering is an added dimension of organizational capacity that involves creation of producer organizations, community networks, community associations, cooperatives, second-tier organizations and sectoral associations (Badini et al. 2018). 
Table 2. Differentiating enabling and asset investments in locally controlled forestry

\begin{tabular}{|c|c|c|c|}
\hline Type & Category & Criteria for investment & Target outputs and outcomes \\
\hline $\begin{array}{l}\text { Enabling } \\
\text { investment }\end{array}$ & & $\begin{array}{ll}\text { - } & \text { Compatible goals } \\
\text { - } & \text { Potential for improvement } \\
\text { - } & \text { Flexibility } \\
\text { - } & \text { Likely to have positive social } \\
\text { and environmental impact } \\
\text { - } & \text { Plan to mitigate any negative } \\
\text { social and environmental } \\
\text { impact }\end{array}$ & $\begin{array}{ll}\text { - } & \text { Transformation } \\
\text { - } & \text { Positive social and environmental } \\
\text { impact } \\
\text { - 'Graduation' to asset investment }\end{array}$ \\
\hline \multirow[t]{4}{*}{ Asset investment } & Value & $\begin{array}{ll}\text { - } & \text { Viability of business } \\
\text { proposition } \\
\text { - } & \text { Measurable risks and returns } \\
\text { - } & \text { Status of forest tenure and } \\
\text { usage rights } \\
\text { - } & \text { Enterprise has sufficient scale } \\
\text { - } & \text { Track record of managers } \\
\text { - } & \text { External factors (country } \\
\text { risk, governance, and market } \\
\text { constraints) } \\
\text { Formal enterprise with } \\
\text { permits } \\
\text { Organizational capacity to } \\
\text { deliver the plan }\end{array}$ & $\begin{array}{l}\text { Attractive, risk-adjusted, financial } \\
\text { return }\end{array}$ \\
\hline & Impact & $\begin{array}{l}\text { All the above, plus: } \\
\text { - Likely to have positive social } \\
\text { and environmental impact } \\
\text { - Plan to mitigate any social } \\
\text { and environmental impact }\end{array}$ & $\begin{array}{l}\text { Some financial return plus positive } \\
\text { social and environmental impact, } \\
\text { as measured and acknowledged by } \\
\text { local stakeholders }\end{array}$ \\
\hline & Product & $\begin{array}{l}\text { Potential to produce product } \\
\text { to right specifications }\end{array}$ & - Reliable supply chain \\
\hline & Banks & $\begin{array}{ll}\text { - } & \text { Liquidity of assets and } \\
\text { - } & \text { Sullateral } \\
\text { - } & \text { Formal enterprient cash flow } \\
\text { permits } \\
\text { - } & \text { Track record of managers } \\
\text { - } & \text { Organizational capacity } \\
\text { - } & \text { External factors (country } \\
\text { risk, governance and market } \\
\text { - constraints) } \\
\text { Sufficient owner's equity } \\
\text { contribution }\end{array}$ & - Debt is serviced and repaid \\
\hline
\end{tabular}

Source: Elson (2012) 


\section{Devolution of forest rights}

The roots of CFEs in Nepal can be found in the devolution of forest rights to diverse types of local UGs that started in the late 1980s. While not a case of outright ownership by communities, the devolution process created a reasonably strong set of durable tenure rights protected by the 1993 Forest Act and 1995 Forest Regulations. These allow communities in the form of UGs to utilize, manage and benefit from access to local forest areas. Once CF, as well as other forms of CBFM such as LHF, took hold, significant improvements in forest cover and condition led community members to consider setting up various types of CFEs. Most CFEs are created by CFUGs. There are many factors working against CFE success in LHF, such as the small number of group members and limited areas of allocated forestland (Albano et al. 2008). CFEs are also formed by buffer zone user groups (BZUGs) although this is a somewhat different type of devolved forest management modality established under a separate law: the 1973 National Wildlife and Conservation Act (Thing and Poudel 2017).

The process of forest rights devolution was initiated in the wake of the significant deforestation that was jumpstarted by forest nationalization in 1957. A first step was to handover forest patches to the newly created unit of local government, the Panchayat, under the 1976 National Forestry Plan (Regmi 1984; Fox 1993). This approach, however, ultimately proved ineffective. The search for a more appropriate management modality led to a new policy framework revolving around the UG idea for CF at the first national CF workshop in 1987 (Arnold and Campbell 1986; Shrestha and Britt 1998). This workshop was followed by the finalization of the landmark Master Plan for the Forestry Sector in 1989 that formally ushered in CF.

As the Panchayat system was subsequently overthrown by a grassroots democratic movement in the 1990s, the newly elected leaders promoted strong legal foundations for forest management. Parliament passed the 1993 Forest Act that formalized and legalized diverse forms of CBFM modalities providing a strong set of tenure rights to UGs. The 1993 Forest Act (Article 43) recognized CFUGs as selfgoverning, independent, autonomous, perpetual and corporate institutions, empowered to acquire, possess, transfer or otherwise manage movable or immovable property (HMG/MoLJ 1993). These rights are allocated indefinitely unless there are abuses of the devolution arrangement.

According to the 1993 Forest Act, the District Forest Office (DFO) can hand over forests to identified UGs "who are willing and capable of managing any part of national forests" (HMG/MoLJ 1993). The Act was later operationalized by the 1995 Forest Regulations and 1995 CF Operational Guidelines (later amended in 2000 and 2014). Over time, District Forest Officers handed over large portions of national forests to local communities based on an agreed OP. Donors actively supported the emergence and growth of CFs working in tandem with the Government of Nepal's (GoN) five-year development plans (increasingly addressing poverty alleviation, as well as gender and social inclusion). The growth in CFUG numbers led to the creation of a federated structure to share experiences as well as lobby for policy changes at the national level. As a result, FECOFUN was established in 1995. Supported by regular national CF workshops (held in 1987, 1998, 2004, 2008 and 2014), CF spread widely, primarily across the Middle Hills but also in the High Hills and the Terai, where significantly different ecological contexts and political dynamics prevailed.

BZCF has a somewhat different history. The fourth amendment of the 1973 National Wildlife and Conservation Act in 1992 established provisions for Buffer Zone (BZ) management to improve relations between protected area management and adjacent communities (Paudel et al. 2007). The subsequent BZ management regulations in 1996 and BZ guidelines in 1999 permitted local community participation in BZ conservation, management and governance. BZUGs for CF could be formed under the BZ management committee or council. As such, the UGs are not autonomous bodies (in the way 
CFUGs are), but work under the leadership of the management committee. UGs could be formed through application to the park warden who also approves their constitution and OP. Although there are no separate guidelines for the management of BZUGs, in practice, they operate in a similar fashion to CFUGs. There is, however, no clarity as to duration of tenure (Thing and Poudel 2017); much depends on the warden, who holds considerable discretionary authority (Jhaveri and Adhikari 2016). Additionally, it is not possible to obtain a tree-felling permit for BZCF and nor is commercial use or marketing of wood products allowed (although excess products can be distributed to neighboring BZUGs). All in all, BZUGs have relatively less autonomy compared to CFUGs. Moreover, in the absence of any overarching network or federation of BZUGs, there is no forum for policy development and political negotiation in favor of their rights. Even so, forest cover and condition, as well as biodiversity, have improved in nearly all BZUGs leading to the subsequent emergence of CFEs focused on tourism and NTFPs (Thing and Poudel 2017).

Today, Nepal's CF is globally regarded as an archetypal model for halting deforestation and forest degradation (Acharya 2002; Hobley et al. 2015; Jhaveri and Adhikari 2016). According to the Department of Forests in 2017, a total of 1,813,478 hectares of national forest have already been handed over as community forests. The scale of community involvement in CF is very significant with about 1.45 million households (35\% of Nepal's population) engaged in 19,361 CFUGs. As the manager of the Kankali BZCF enterprise explained: "Before we started informal conservation as a CF in 1990, the hills were completely denuded. People would cut down whatever grew here for firewood and fodder, and cattle and goats were grazed openly. Water was so scarce that people would not give their daughters in marriage to men here. All this lush green forest with valuable sal (Shorea robusta) trees is the progress achieved since then. The DFO handed over this forest as a CF to us."

CFUGs are arguably Nepal's most robust and successful local-level institutions. Functioning as the de facto local government during the violent conflict and long process of political transition, CFUGs have grown in number from 29 groups in 1990, to 11,102 in 2000, 17,742 in 2010 and 19,361 in 2017 (Paudel et al. 2018). The scope of CF activities has substantially widened from its early focus on forest protection and subsistence use to a more integrated approach to accommodate wider social and economic objectives including poverty alleviation, gender and social inclusion, as well as forest enterprise development (FAO 2009; NPC 2017). CF's contribution to poverty alleviation, legal advocacy, capacity building, social equity and the institutionalization of democratic governance processes on a wide scale have had a deep and lasting effect across the country (Kanel and Niraula 2017). As the considerable efforts of forestry UGs to improve their local forests brought success, they leveraged their tenure rights to attract investment to help spawn a variety of forest-based enterprises, including timber processing, tourism activities, and processing and marketing of NTFPs. 


\section{Emergence and growth of community- managed forest enterprises}

This section provides an overview of the key characteristics of the CFE sector focusing on how the government, donors and non-governmental organizations (NGOs) have supported its emergence and growth following forest rights devolution. It provides a contextualized understanding of the CFE sector for the subsequent detailed analysis of how regulatory and non-regulatory factors have affected investment dynamics among the 12 CFEs studied.

Four major developments have supported the emergence of CFEs from the 1990s onwards: adequate natural resources in forested areas, growing markets (both domestic and export), policy frameworks and external support (Paudel et al. 2018). With a high level of forest cover, as well as floral biodiversity, Nepal's CFEs have emerged in an ecological context that is rich in a wide range of forestbased resources. CFEs can be classified into four types: timber, NTFPs, ecosystem services (tourism and carbon) and forest bio-energy (Subedi et al. 2014). CFE activities can include harvesting forest products, grading and sorting, labeling, processing, trading, transporting and manufacturing, be it on an informal or formal basis.

The government has supported the NTFP trade since the mid-1990s (Edwards 1996; Subedi 1999). The bulk of NTFPs are exported (formally or informally) to India with much smaller volumes to Europe, the Americas or other Asian countries. Although most CFEs are focused on NTFPs, they are largely involved in the collection and trade of raw herbs because of the processing industry's poor development. For example, a 2016 study in the Koshi Hills found that a hundred of the 144 forestryrelated enterprises were NTFP-related (Rai et al. 2006). The government's singular focus on forest conservation for decades has meant that, until recently, there has been little interest in appropriate forms of silvicultural management to support CFEs engaged in the timber and other wood product industries (see Paudel et al. 2019).

Initially, the momentum to create CFEs was catalyzed by the government, donor agencies and NGOs. Later, as policy and legal developments came to support the growing trade in NTFPs (especially MAPs), there has been considerable, if at times unstable, growth in the CFE sector (Acharya 2013). The government's overall ambition for forest-based enterprises was driven by the five-year plans from the early 1990s onwards to promote poverty reduction and greater social inclusion, and later by trade integration strategies and policies in the 2000s.

Even though the existing trade in MAPs (of about 100 plant species) in the international market contributes to about one-third of forestry gross domestic product (AEC/FNCCI 2012), the financial benefit to villagers remains limited. Within the MAPs trade, highland resources have relatively higher value in contrast to lowland ones (Edwards 1996). MAPs collectors (with weak bargaining power) have received low remuneration in contrast to the profit that traders make at different nodes of the value chain (Edwards 1996; Subedi 1999). Most importantly, because the value chain is not highly consolidated, there are high transaction costs (Acharya 2005; Lamsal et al. 2017). Only a few NTFPs such as wood apple (bael) have been processed into juices by CFEs to sell in the market. This has led to arguments that there is misplaced optimism in NTFPs' economic possibilities, and that their promotion should be seen as complementary to timber-based enterprises that yield much greater income, especially in the Terai (Banjade and Paudel 2008). From the viewpoint of villagers, however, there are other considerations involved in CFE startup, such as availability of required capital investment, time horizon for profit-making and multiple risk issues (Pyakurel and Baniya 2011). Based on research from 195 CFEs in 23 districts of Nepal, mean investment in ecotourism (US\$22805.09) and wood-based industries (US\$11252.42) was much higher than in NTFPs (US\$2628.03). Moreover, 
employment generation was found to be highest in wood-based industries (2527 man-days) followed by ecotourism (1490 man-days) and then NTFPs (1093 man-days) (Dhakal et al. 2018).

It has been hard to obtain an accurate picture of the scope and geographical range of CFEs in Nepal because of the way data are collected. The Department of Forests started to collect comprehensive data on the collection and trade of MAPs (about 164 plant species) after 2006 (Rai et al. 2016) although an analysis of trends is not readily available. The Department of Cottage and Small Industries (DCSI) data aggregates agriculture and forestry enterprises together. This data indicates that, in 2017, there were some 45,459 such enterprises (out of the total 209,275) (Paudel et al. 2018). Of these, 12,591 (about 28\%) were small-scale forest enterprises (SSFEs). Based on sub-categorization, some 69\% were furniture enterprises, $17 \%$ were non-wood forest product enterprises (small-scale), $13 \%$ were sawmills, with plywood and veneer producers being less than $1 \%$. In distinct contrast, a 2014 fieldbased study of private sector involvement in the forestry sector (that collected primary as well as secondary data) determined that there were about 41,000 SSFEs (Subedi et al. 2014). Of these, some $66 \%$ were involved in primary production, with the rest engaged in processing, manufacturing and trade. The significant difference in estimates, most likely, stems from the fact that many SSFEs are not formally registered, even if operational. Therefore, it is difficult to determine trends over time for specific types of CFEs.

Recent analysis indicates that forest-based industries hold considerable growth potential likely to generate about NPR 88 billion (about US\$0.88 billion) with 0.40 million fulltime employment opportunities under a conservative scenario, and NPR 370 billion (about US $\$ 3.70$ billion) with 1.38 million fulltime employment opportunities under an optimistic scenario (Subedi et al. 2014). Therefore, there is strong interest among donors, NGOs, CFEs and traders in addressing the numerous obstacles (regulatory and non-regulatory) facing the CFE sector (Acharya 2005; Paudel et al. 2018).

As noted earlier, starting from the late 1980s, policy support began to grow for CFEs especially NTFP-oriented ones (see Table 3). It was the 1988 Master Plan for the Forestry Sector that first set out specific objectives for NTFPs (MAPs, lokta (Daphne bholua) paper, pine resin, kattha (from Acacia catechu), sabai (Eulaliopsis binata) grass (for paper) and canes/bamboo) (Subedi 1999; Sharma and Shrestha 2011). The plan's Forest Based Industrial Development Plan sought to promote job creation, processing facilities and cultivation of wild-collected medicinal plant species. Thereafter, although the 1993 Forest Act and 1995 Forest Regulations provided the foundational legal framework for forest rights devolution, there were no clear provisions for the utilization and conservation of NTFPs. For example, CFUG OPs did not have any provision for NTFP management (Ojha 2000). In light of this, the Herbs and NTFP Development Policy was introduced in 2004 (Sharma and Shrestha 2011).

Almost a decade later, in the early 2010s, the MFE introduced the "Forestry for Prosperity" policy in order to create green jobs, promote economic growth, and ensure environmental sustainability. Mirroring this policy, FECOFUN adopted the motto "One Community Forest, One Enterprise." Consequently, both the 2015 Forest Policy and the 2015 Forest Sector Strategy have both set out support for enterprise development (community-based and private) even though these principles have not yet been reflected through the necessary amendments of the 1993 Forest Act and 1995 Forest Regulations to transform their practical implementation (Baral et al. 2016). The needs of wood-based enterprises also began to be addressed with the 2015 Forest Sector Strategy calling for a review of the timber royalty system in order to increase the amount of domestic timber supplied to local markets. 
Table 3. Policies and laws regulating CFEs in Nepal

\begin{tabular}{|c|c|}
\hline Policies and Laws & Enterprise-Related Focus \\
\hline 1957 Import and Export (Control) Act & $\begin{array}{l}\text { Government can ban export of any NTFPs or MAPs to } \\
\text { control trade of endangered or threatened or Convention } \\
\text { on International Trade in Endangered Species of Wild } \\
\text { Fauna and Flora (CITES) listed species }\end{array}$ \\
\hline 1973 National Wildlife and Conservation Act & $\begin{array}{l}\text { Empowers government to establish national parks, } \\
\text { reserves or conservation areas }\end{array}$ \\
\hline \multirow[t]{2}{*}{1989 Master Plan for Forestry Sector } & Allows forests to be utilized to benefit people \\
\hline & High-value medicinal products \\
\hline 1992 Cooperative Act & $\begin{array}{l}\text { Cooperatives can operate forest-based enterprises, and } \\
\text { receive tax exemption }\end{array}$ \\
\hline \multirow[t]{2}{*}{1992 Industrial Enterprises Act } & Small and large-scale industries can be established \\
\hline & $\begin{array}{l}\text { Among four highly prioritized traditional cottage } \\
\text { industries: agriculture and forest-based industry, and } \\
\text { NTFP enterprises }\end{array}$ \\
\hline \multirow[t]{2}{*}{1993 Forest Act } & Devolves forest management \\
\hline & $\begin{array}{l}\text { Establishes CF, LHF and other forest management } \\
\text { modalities }\end{array}$ \\
\hline \multirow[t]{3}{*}{1995 Forest Regulations } & $\begin{array}{l}\text { Sets out rules regarding whether, how and when forest } \\
\text { products may be collected, sold and distributed }\end{array}$ \\
\hline & $\begin{array}{l}\text { Stipulates requirements for reforestation or } \\
\text { rehabilitation of forests after harvesting }\end{array}$ \\
\hline & $\begin{array}{l}\text { Provides rules on how regulations will be implemented } \\
\text { by the DFO }\end{array}$ \\
\hline \multirow[t]{2}{*}{1996 Buffer Zone Management Regulations } & $\begin{array}{l}\text { Written approval of Department of National Parks and } \\
\text { Wildlife Conservation needed before registering any } \\
\text { industry in buffer zone }\end{array}$ \\
\hline & $\begin{array}{l}\text { Department shall provide guidelines for operation of } \\
\text { industries }\end{array}$ \\
\hline 1997 Environmental Protection Act and & Requires preparation and approval of Initial \\
\hline 1997 Environmental Protection Regulation & $\begin{array}{l}\text { Environmental Evaluation (IEE) or Environmental } \\
\text { Impact Assessment (EIA) to collect and/or establish } \\
\text { enterprises based on NTFPs. This is not required for } \\
\text { establishing cottage industries }\end{array}$ \\
\hline 1999 Buffer Zone Management Guideline & $\begin{array}{l}\text { Supports community development programs provided } \\
\text { there is no negative environmental impact }\end{array}$ \\
\hline 2004 National Agriculture Policy & $\begin{array}{l}\text { Promotes cooperatives for agriculture and NTFP } \\
\text { commercialization }\end{array}$ \\
\hline \multirow[t]{3}{*}{2004 Herb and NTFP Policy } & $\begin{array}{l}\text { Allows private sector participation in NTFP } \\
\text { development }\end{array}$ \\
\hline & Emphasizes local processing \\
\hline & Promotes conservation of high-value herbs and NTFP \\
\hline 2007 Plant Protection Act & $\begin{array}{l}\text { In order to import or export of NTFPs/MAPs (raw } \\
\text { or processed products), the government requires a } \\
\text { quarantine certificate to prevent disease, and sanitary or } \\
\text { phyto-sanitary certificate to maintain hygiene }\end{array}$ \\
\hline 2007 Resin Collection (Procedures) Regulation & $\begin{array}{l}\text { Sets out procedures for identifying area, collecting as well } \\
\text { as fire and environmental management of forests for resin } \\
\text { collection for all types of forests (including CFUGs) }\end{array}$ \\
\hline 2012 NTFP Inventory Guideline & $\begin{array}{l}\text { Describes the inventory process for leaf, root, bark, and } \\
\text { flowers as well as whole plant for NTFPs. Provides a } \\
\text { detailed inventory method for } 30 \text { NTFPs and MAPS } \\
\text { that are prioritized }\end{array}$ \\
\hline
\end{tabular}


Table 3. Continue

2014 Community Forestry Guidelines

Develops forest-based enterprise to support livelihoods and employment generation

Facilitates financial and technical support from service providers

Supports preparation of business plan

Facilitates cooperation with other CFUGs and organization

Promotes the concept of "One CFUG-One Enterprise"

CFUGs can partner with the private sector to operate forest-based enterprise(s)

2014 Procedural Guidelines for the Collection, Sales and Distribution of Forest Products

Outlines the arrangements and procedures to be followed while collecting, selling and distributing forest products (timber, fuelwood and NTFPs) in governmentmanaged forests, protected forests, collaborative forests and other forests

Sets out guidelines for sawmills harvesting trees as well as export of forest-based products

\begin{tabular}{|c|c|}
\hline 2014 National Biodiversity Strategy and Action Plan & Promotes ecotourism in protected areas \\
\hline & $\begin{array}{l}\text { Links biodiversity conservation to job creation and } \\
\text { entrepreneurship }\end{array}$ \\
\hline & $\begin{array}{l}\text { Domestication of locally threatened high-value species } \\
\text { (NTFP/MAPs) }\end{array}$ \\
\hline 2015 Trade Policy & Promotes NTFP product development and value chains \\
\hline 2015 Forest Policy & $\begin{array}{l}\text { Gives high priority to promoting forest-based } \\
\text { enterprises through private sector involvement }\end{array}$ \\
\hline & $\begin{array}{l}\text { Envisions forest development fund for enhancing } \\
\text { private sector involvement }\end{array}$ \\
\hline 2015 Forest Sector Strategy & $\begin{array}{l}\text { Focuses on enhancing forest productivity and } \\
\text { sustainable supply of forest products and services }\end{array}$ \\
\hline & $\begin{array}{l}\text { Promotes community-based and private enterprises to } \\
\text { improve livelihoods and forest sector's contribution to } \\
\text { national economy }\end{array}$ \\
\hline 2017 Industrial Enterprises Act (revised from 1992) & Small and large-scale industries can be established \\
\hline & $\begin{array}{l}\text { Among four highly prioritized traditional cottage } \\
\text { industries: agriculture and forest-based industry, and } \\
\text { NTFP enterprises }\end{array}$ \\
\hline 2017 Local Government Operation Act & $\begin{array}{l}\text { Collects royalties from the operation and management } \\
\text { of CFs }\end{array}$ \\
\hline & $\begin{array}{l}\text { Promotes collection, production, processing, promotion, } \\
\text { and value chain management for local-level MAPs and } \\
\text { NTFPs }\end{array}$ \\
\hline & $\begin{array}{l}\text { Provides for local wildlife tourism and income } \\
\text { generation }\end{array}$ \\
\hline
\end{tabular}

Source: Adapted from Gauli and Hauser (2009); Subedi et al. (2014); Baral et al. (2016); Rai et al. (2016); Paudel et al. (2018)

Over time, the high export potential of NTFPs was reflected in new industrial and trade policies as well. The 2015 Trade Policy underscored the need to support its commercialization and export promotion (Sharma and Shrestha 2011). The same principles were reflected in the 2010 National Trade Integration Strategy and continued into the 2016 strategy, the third generation of its kind (Ministry of Commerce 2016a). Agro and forest products (in particular cardamom, ginger, tea and MAPs) were one of the three primary trade areas to be advanced. These products, the strategy asserted, would benefit from product and value chain development, as well as modern storage and processing technologies. Notably, the NTFP sector was ranked high in terms of its socioeconomic impact and medium in terms 
of its export potential. MAPs, in particular, were identified as having high positive impact on women (Ministry of Commerce 2016b). In parallel, the 2010 Industrial Enterprise Policy and Annex 9 of the 2017 Industrial Enterprise Act recognized agricultural and forest-based enterprises as nationally prioritized enterprises. The Federation of Nepalese Chamber of Commerce and Industry (FNCCI) has also consistently supported the NTFP sector's expansion.

The same priorities were promoted within the five-year national development plans. Starting from the Eighth Five-Year Plan (1991-1997) that included herb development within the forestry sector, to the Three-Year Plan Approach Paper (2010-2013)5, NTFP's role in poverty alleviation and improving social inclusion as well as encouraging public-community-private partnerships has been highlighted (Sharma and Shrestha 2011). For example, the Three-Year Interim Plan (2007-2010) emphasized programs for building and marketing the NTFP sector industry (by market mapping value addition along herb-based industry value chains), in particular by employing adibasi janajatis (indigenous nationalities). Furthermore, it aimed to create herb processing cooperatives in the Middle Hills and High Hills. With the adoption of an inclusive constitution in 2015 that promotes a federal governance structure, and a general consensus on development and prosperity as the path for a new and stable Nepal, it is anticipated that government support for CFEs will be consolidated.

The spirit of these varied policies and strategies have been taken forward across a range of government and donor-supported initiatives. Subsequent diagnosis of the challenges faced by CFEs has produced a broad-brush understanding of needs. The government's Micro-Enterprise Development Programme (MEDEP) implemented by the Ministry of Industry from the late 1990s included forest-based micro-enterprises (about $18.6 \%$ of their total) (MEDEP 2010). Covering 36 districts, nearly $75 \%$ of participants moved out of poverty, while the return on investment ranged from $71 \%$ to $157 \%$ with forest-based and agriculture having the lowest. MEDEP has also examined challenges within particular forest value chains such as chiuri (Diploknema butyracea) herbal soap (MEDEP 2011) and timber enterprises (MEDEP 2013). In 2006, the FNCCI launched the "One Village One Product" program (later continued as the "One District One Product" program) utilizing a public-private partnership model that included NTFPs (Lamsal et al. 2017). The DCSI also sought to create micro and small entrepreneurs, particularly for marginalized and disadvantaged groups. However, without sufficient funding and human resources, they have not been particularly successful.

Donors have long supported projects on forest-based enterprises in specific regions of Nepal. Starting with the Koshi Hills Rural Development Programme, followed by the Livelihoods and Forest Programme and later the Multi Stakeholder Forestry Programme (MSFP), the Koshi Hills have benefitted from considerable donor engagement on CFEs. The most recent projects have supported about 100 enterprises over a 3-year period in the early 2010s (Kunwar et al. 2009; Rai et al. 2016). Working in districts such as Dolakha, the Nepal Swiss Community Forestry Project adopted a pro-poor entrepreneurship approach (Pokharel et al. 2006). CARE's initiatives in the late 2000s in the Churia's Sarlahi and Mahottari district for improving livelihood security of poor and vulnerable people through watershed management and social equity focused on NTFP/MAPs enterprises (Khanal and Bhujei 2008).

Among the NGOs, the Asia Network for Sustainable Agriculture and Bioresources (ANSAB), has long been involved in promoting NTFP-related CFEs providing significant analyses of their geographical scope, opportunities and gaps (Subedi 1999; Ojha 2000; Subedi et al. 2002, 2014). ANSAB has been the FAO's Forest Connect program's key partner in Nepal. More recently, the FAO's Forest Farm Facility has been working, together with the International Union for Conservation of Nature (IUCN), FECOFUN and the Federation of Cottage and Small Scale Industry to create a cross-sectoral platform for relevant stakeholders to discuss their CFE business concerns and share lessons (Baral et al. 2016).

5 After a gap of 12 years, it is anticipated that the Fifteenth Five-Year Plan will be unveiled later in 2019. 
Within this overall picture, it is imperative to note that the private sector, while interested in engaging with CFEs, are at a crossroads debating whether to continue and expand operations, or withdraw from the forest sector altogether (Subedi et al. 2014). On the one hand, there are significant supply constraints and governance problems, and on the other hand, the promise of high returns on investment with low risk continues to draw their interest. 


\section{Regulatory frameworks governing community-managed forest enterprises}

This chapter provides an analysis of how various regulatory frameworks affect investment dynamics within Nepal's CFEs focusing on the 12 CFEs under study.

The 2015 Constitution of the Federal Republic of Nepal ${ }^{6}$ sets out that it is the government's responsibility to support lawful activity that generates positive economic growth, while protecting public health as well as the country's forest and environmental endowment. A concrete sense of the opportunities available to CBFM institutions to set up CFEs can be found within the relevant legal and policy frameworks. Currently, CBFM institutions face a complex regulatory structure that is neither readily understood by rural residents nor easy to comply with. They aim to support, as the constitution asserts, domestic investment for national economic development through a tri-partite structure of public, private and cooperative sector partnerships. This is reflected in the spectrum of institutional modalities available for establishing a CFE. Different pieces of legislation introduced at different times permit, in an overall sense, the registration of various types of commercial entities including micro and small (or larger-scale) enterprises, cottage industries, cooperatives and private limited companies. All too often, the process required to register any commercial entity is onerous in terms of time, expense and knowledge required.

Beyond registration of the enterprise, there are a range of regulations governing the distance rule (how far CFEs need to be set up from forest areas), transport and export permits, environmental quality and standards, as well as taxes and royalties. These create a series of administrative hurdles that become an onerous burden for CFEs. Additionally, many problems emerge from how these policies are misinterpreted and inappropriately implemented at the local level (see Kunwar et al. 2009; and Rai et al. 2016 for insights on Koshi Hills NTFP-oriented CFEs). This together with rapid changes in the policy environment inadvertently pose greater risks for existing enterprises (Subedi et al. 2002). Even so, the fact that CFEs continue to be created despite these imposing obstacles indicates that the anticipated set of benefits are still worthwhile.

In terms of the benefits of forest rights devolution, the perception among UG members is that their tenure rights, in practice, are not as strong as originally presumed. Many among the 12 CFEs studied have asserted that, given the regulatory difficulties they have faced, the tangible rights they had been granted were not as high as originally perceived. In the Gobardiha Wood and Furniture Industry (that provides sawmilling services), one member of the management team observed that they originally believed they had high levels of tenure rights (five on a scale of one to five). He noted that, "After being rejected following several visits to the DFO trying to get our enterprise registered, we now feel we have been granted nothing and that we are no more than a 2." Even though the DFO is following the distance rule requirements, the community perception becomes one of lack of tenure security. Similarly, when CFUG members sought to establish the Tamakoshi Resin and Turpentine Industry, the DFO's refusal to grant permission led to the enterprise managers expressing that "we are at a score of one." Generally, CFEs considered the regulatory environment as restrictive rather than supportive. The strengths and gaps of the existing regulatory frameworks governing CFEs are analyzed below.

\subsection{Institutional modalities of community-managed forest enterprises}

Starting from the 1992 Cooperatives Act, the 2006 Companies Act to the latest 2017 revised Industrial Enterprise Act (from the 1992 Act), there have been expanding opportunities for registering forest-based

6 The Constitution of the Federal Republic of Nepal (2015); Article 17(2). 
enterprises of different institutional modalities: enterprises (micro, small, medium and large), cottage industries, cooperatives and private limited companies. Most recently, the 2010 Industrial Enterprise Policy and related Annex 9 of the 2017 Industrial Enterprise Act have prioritized agricultural and forest-based enterprises such that they are the beneficiaries of incentives and tax exemptions to promote growth.

Each of these institutional modalities offers particular types of opportunities. For example, registering as an enterprise (micro, small, medium or large) or cottage industry under the 2017 Industrial Enterprise Act is suitable for sole proprietorship or a partnership firm. In such cases, the firm is registered under the name of a reliable person as proprietor such as the UG chairperson. Putatively a private entity, this is in practice managed by the UG or the enterprise sub-committee. The other option, under the 2006 Companies Act, involves a larger number of owners. The 2017 Industrial Enterprise Act now offers UGs another registration channel. Such forms of registration enable CFEs to undertake processing, transporting and marketing of their products. In addition to registration, CFEs have to be registered with a permanent account number for tax purposes. Despite the fact that renewal of status under the 2017 Industrial Enterprise Act grants a fee waiver, not all CFEs renew their enterprises but continue operating despite losing their legal registration.

In reality, many CFEs do not register at all but operate based on the DFO's approval of their OP (in the form of a certificate of alienation) that describes their specific production activities. The DFO's approval on their letterhead (such as a CFUG's) allows them to sell their products in the marketplace. They have not faced any significant obstacles to date, despite the lack of legally valid documents.

Table 4 summarizes the different types of CFE registration in current existence and provides a brief assessment of legal gaps and areas for improvement.

Table 4. CFE modalities in Nepal

\begin{tabular}{|c|c|c|}
\hline $\begin{array}{l}\text { CFE } \\
\text { modality }\end{array}$ & Description & Legal gaps and areas for improvement \\
\hline $\begin{array}{l}\text { Micro, small } \\
\text { and other } \\
\text { enterprises }\end{array}$ & $\begin{array}{l}\text { Many CFEs have been registered with DCSI and } \\
\text { are operating as enterprises (micro, small, medium } \\
\text { or large) or cottage industries based on the } 2017 \\
\text { Industrial Enterprise Act (amended from } 1992 \\
\text { version). The revised } 2017 \text { Industrial Enterprise Act } \\
\text { has largely incorporated the earlier provisions on } \\
\text { registration and operation. } \\
\text { CFEs operated by CBFM institutions such as } \\
\text { CFUGs (or consortia of CFUGs) are registered } \\
\text { under this modality. } \\
\text { The } 2017 \text { Industrial Enterprise Act sets up the } \\
\text { classification of industrial types based on size of } \\
\text { fixed assets. } \\
\text { The } 2017 \text { Industrial Enterprise Act includes a provision } \\
\text { for providing land for the establishment of CFEs. } \\
\text { Incentives and opportunities for micro-enterprises: } \\
\text { Registration of micro-enterprise without registration } \\
\text { charge; } \\
\text { No requirement to submit a recommendation from } \\
\text { the local government; } \\
\text { The recommendation of ward level local government } \\
\text { required for those micro-enterprises that may affect the } \\
\text { society and/or the environment; } \\
\text { Income tax exemption for the first five years of } \\
\text { enterprise operation; } \\
\text { Subsidy and seed grants to establish micro- } \\
\text { enterprises in highly remote areas; and } \\
\text { Ownership by women entrepreneur only is entitled to } \\
\text { 35\% discount on industrial registration and } 20 \% \text { discount } \\
\text { on industrial property registration. }\end{array}$ & $\begin{array}{l}\text { The DCSI has issued a circular to } \\
\text { help follow the provisions of the } 2016 \\
\text { Enterprise Procedural Manual }{ }^{a} \text { for the } \\
\text { registration of furniture-based and timber } \\
\text { processing CFEs. This manual imposes } \\
\text { additional conditions for the registration of } \\
\text { such CFEs and some points in that circular } \\
\text { contradict the provisions mentioned in the } \\
\text { subsequent } 2017 \text { Industrial Enterprise Act. } \\
\text { This circular requires a CFE that depends } \\
\text { on raw materials to be collected from } \\
\text { national forests, to receive an approval } \\
\text { letter from the MFE. Such administrative } \\
\text { procedures are not only complex but it is } \\
\text { difficult to obtain such approval. } \\
\text { A land ownership certificate and citizenship } \\
\text { card during the registration of a CFE } \\
\text { is required. This provision has created } \\
\text { problems for the poor and landless. } \\
\text { Likewise, CFUGs also do not possess a } \\
\text { land ownership certificate for the forestland } \\
\text { falling within a CF's territory. Although } \\
\text { CFUGs seek to register their CFE in their } \\
\text { name based on their registration certificate } \\
\text { (which recognizes them as a legal entity), } \\
\text { in practice they also need to submit the } \\
\text { citizenship cards of at least one CF member } \\
\text { during the registration process. }\end{array}$ \\
\hline
\end{tabular}




\begin{tabular}{|c|c|c|}
\hline $\begin{array}{l}\text { CFE } \\
\text { modality }\end{array}$ & Description & Legal gaps and areas for improvement \\
\hline Cooperatives & $\begin{array}{l}\text { The objective of the } 2017 \text { Cooperative Act is to } \\
\text { enhance the socioeconomic status of farmers, } \\
\text { craftspeople (kaligadh), laborers, low-income and } \\
\text { marginalized groups, or local consumers. The } 2012 \\
\text { National Cooperative Policy seeks to facilitate the } \\
\text { development and expansion of cooperatives. } \\
\text { Forest product-based cooperatives can provide } \\
\text { service to their members and can also produce } \\
\text { goods from forest products as per their by-laws } \\
\text { which are approved by the local government's } \\
\text { Industry Development Section. They collect } \\
\text { financial resources from their members to establish } \\
\text { such types of CFEs. } \\
\text { Such cooperatives are deemed to be more beneficial } \\
\text { to poor households, women and marginalized } \\
\text { groups because they are provided with a platform } \\
\text { that supports employment and livelihood benefits. } \\
\text { There are presently about } 200 \text { such forest-based } \\
\text { cooperatives. A handful of these cooperatives run } \\
\text { timber-based enterprises with the involvement } \\
\text { of and investment from CFUGs. However, such } \\
\text { enterprises are also required to register as an } \\
\text { enterprise under the } 2017 \text { Industrial Enterprise } \\
\text { Act in order to process forest products. The } 2002 \\
\text { Income Tax Act has assured income tax exemption } \\
\text { for these forest product-based cooperatives. }\end{array}$ & $\begin{array}{l}\text { - The overall provisions of this Act have been } \\
\text { developed particularly for the purposes } \\
\text { of saving and credit-based cooperatives. } \\
\text { Therefore, the existing provisions in this } \\
\text { Act are not designed with the needs of } \\
\text { forest-based cooperatives in mind. } \\
\text { - The Act and different government circulars } \\
\text { have sought to limit the working area of a } \\
\text { cooperative to the jurisdictional boundary } \\
\text { of one local government unit such as } \\
\text { municipalities (nagarpalika) and rural } \\
\text { municipalities (gaonpalika). In practice, } \\
\text { this is not sufficient for the collection } \\
\text { of NTFPs as well as timber to supply an } \\
\text { enterprise. } \\
\text { Similarly, if any persons or any local } \\
\text { community wants to register a forest } \\
\text { product-based cooperative, they need to } \\
\text { get approval from the Registrar of the } \\
\text { Cooperative Department which is tedious } \\
\text { and time consuming. }\end{array}$ \\
\hline $\begin{array}{l}\text { te } \\
\text { ed } \\
\text { any }\end{array}$ & $\begin{array}{l}\text { Some CFUGs have solely or jointly established a } \\
\text { private limited company to operate a forest enterprises } \\
\text { based on the legal provisions of the } 2006 \text { Companies } \\
\text { Act. The private limited company model creates } \\
\text { opportunity to promote a joint venture between } \\
\text { CFUGs and individual/private investors. Experience } \\
\text { has shown that such modalities are successful } \\
\text { in creating value addition. A number of CFEs } \\
\text { manufacturing timber, handmade paper, essential } \\
\text { oils and herbal juice have been established under this } \\
\text { modality because it permits pooled investment from } \\
\text { many CFUGs as shareholders and opens the door } \\
\text { to community-private partnerships. Most privately } \\
\text { owned forest-based enterprises that provide ecosystem } \\
\text { services are registered under this modality. } \\
\text { It is imperative for the company to maintain } \\
\text { transparent governance through its own } \\
\text { memorandum and regulations. } \\
\text { There are no tax exemptions for forest product- } \\
\text { based companies. }\end{array}$ & $\begin{array}{l}\text { A company can only be registered at the } \\
\text { central level through an online registration } \\
\text { system. Therefore, without improving the } \\
\text { capacity of UGs, it is difficult for them to } \\
\text { follow the company registration process. } \\
\text { Given the lack of tax exemption, CFUGs } \\
\text { are hesitant to register under the company } \\
\text { model because they are wary of the tax } \\
\text { system's complexities. }\end{array}$ \\
\hline $\begin{array}{l}\text { Forest } \\
\text { owner as } \\
\text { entrepreneur }\end{array}$ & $\begin{array}{l}\text { The } 2017 \text { Industrial Enterprise Act has recognized } \\
\text { forest-based enterprises (community-based or } \\
\text { private) as a national priority.b After registration of } \\
\text { these CBFM groups, they can operate their forest } \\
\text { products-based business upon the approval of OPs } \\
\text { and other legal requirements related to fiscal laws } \\
\text { and environmental measures. Earlier, section 30(a) } \\
\text { of the } 1993 \text { Forest Act (second amendment 2016) } \\
\text { had also given rights to CFUGs to establish and } \\
\text { operate forest-based enterprises based on their } \\
\text { approved OPs. }\end{array}$ & $\begin{array}{l}\text { - Compliance with forest/environment- } \\
\text { related laws and provisions imposes } \\
\text { additional conditions for the registration } \\
\text { and operation of forest-based enterprises. } \\
\text { Despite legal recognition by the } 2017 \\
\text { Industrial Enterprise Act, community-based } \\
\text { and private forest owners have to separately } \\
\text { register their enterprise (micro, small or } \\
\text { otherwise) or cottage industry if they want } \\
\text { to trade their semi-processed or processed } \\
\text { products in the market. }\end{array}$ \\
\hline
\end{tabular}

\section{Notes:}

a This circular was issued on 3 April 2017.

b Annex 9 of the 2017 Industrial Enterprise Act.

Source: Adapted and expanded from Paudel et al. (2018) 


\subsection{Government institutional arrangements for service delivery}

The critical issue of service support by government agencies, particularly at the local level, plays an important role in how well laws and policies are implemented. A number of key government agencies are involved in providing services at the central and local levels. CFEs have to work with these varied regulatory bodies at different stages in order to obtain specific types of approval. At the national level, the key bodies are: within the Ministry of Industry, Commerce and Supplies, the DCSI, and the Office of Company Registrar; within the Ministry of Land Management, Cooperatives, and Poverty Alleviation, the Department of Cooperatives; and within the MFE, the Forest Enterprise Division. In parallel, at the local level, there is the Office of DCSI, the Industry Development Section, Divisional Office of Cooperatives and the DFO. Based on new constitutional provisions, regulatory agencies will be merged under each local government working as relevant sections. The role of the local government, as it relates to CFEs, will be significantly enlarged should its budgetary and technical capabilities be strengthened.

Among the 12 CFEs studied, the overall perception was that governmental support was uneven. When it came to meeting planning procedures and requirements, service support was high, whereas for providing supportive training and skill development as well as encouraging private sector partnership, it was low. Only where there were specific governmental programs, such as for the NTFP sector, was there greater support for the poor for NTFP collection and marketing. By and large, CFEs believed that the levels of patronage, corruption and interference together with obstacles from DFOs implementing existing regulatory frameworks were high. A CFE management team member of the Gobardiha company said, "Even though the DFOs are personally supportive of our endeavors, they do not provide us with the required document for registration. They say that they are bound by regulations. As community institutions, we only wish to know what we can do to make it easier for us to register our enterprises just like the private ones."

Mobilizing political and social connections to exert pressure on officials for timely decisions or pleasing them through diverse strategies including gifts, special treatments and even bribing have become the coping strategies of CFUG/CFE leaders in difficult situations. For instance, the Baghmara BZCF sometimes used to provide elephant rides through fast tracks (escaping the queue) or at reduced rates/free to the officials. However, given the never-ending demands for such concessions, they decided to stop entertaining such requests. Instead they preferred to fulfill all the formal requirements in furnishing documents or paying taxes.

Another strategy for ensuring the support of government officials has been to establish strategic political and social networks by inviting them to the CFE's inauguration or be the "chair" of a meeting. For example, the Kankali BZCF was inaugrated by the then Regional Directorate. This prevented other GoN officials, including the DFO, from obstructing this CFE's activities.

In the absence of government training for CFEs, they typically approach donor-funded projects or NGOs to carry out capacity-building work. For example, the Bishasaya Community Wood Apple and Fruit Processing Industry and the Binayi Organic Manure Enterprise were trained by the MSFP. While there is little research on the budgetary and service support dimensions of these agencies for CFEs, one recent study on the government's "NTFP Development Program" indicated that budgetary support over the period 2015-2017 had been uneven (Paudel 2018). In 2015/16, the budget was US $\$ 0.4$ million, in 2016/17 it was US\$4.02 million, and in 2017/18 it was US\$2.76 million. Among the five programmatic areas of resource generation, enterprise development and value addition, institutional development, coordination, extension and capacity building, and resource development, the first two areas received the greatest budgetary allocation of $37 \%$ and $34 \%$, respectively.

Office of Cottage and Small Industries: The agency provides services and support to develop business plans, and other necessary administrative steps for the registration and operation of an enterprise. 
Applicants indicate the overall performance is satisfactory. Sometimes the Office makes additional documentary demands such as land ownership certificate for the registration of an enterprise which can pose difficulties.

Divisional Office of Cooperatives: Generally, this office is rarely involved in registration of forest-based cooperatives because this requires a large forest area for raw material collection. Moreover, the situation is complicated by the additional rule that any cooperative covering areas that go beyond the administrative jurisdiction of one local government needs approval from the central-level Department of Cooperatives.

District Forest Office: The DFO plays a critical role in the registration and operation of forest-based enterprises because, in the absence of the DFO's recommendation letter, the Office of Cottage and Small Industries and the Divisional Office of Cooperatives will not register a forest-based enterprise or cooperative. The DFO also possesses the authority to implement the distance rule by identifying the distance between forest areas and enterprise location. In a related sense, the DFO also has a substantial role in approving the forest $\mathrm{OP}$ that regulates the supply of raw materials as well as scope of forestbased enterprises.

Office of Company Registrar: Based in Kathmandu, this agency has centralized the company registration process through an online system.

\subsection{Distance-related rule}

One of the primary legislative obstacles faced by CFEs is the legal stipulation concerning the distance that is to be maintained between forest-based enterprises and forested areas first set out in the 1995 Forest Regulations. The rationale behind this distance-related rule is to protect forest areas from fire, illegal encroachment and illegal harvesting of forest products. This stems from a strict conservationist approach that seeks to set up disincentives for extraction of wood-based products for commercial purposes. Even NTFPs have to follow a related and stringent process such that NTFP-based CFEs must be located 0.25 to $1 \mathrm{~km}$ away from the forest (GoN 2014). Moreover, no permanent structure can be set up for processing forest products within the CF's forestlands (GoN 2014). Given that most forestlands in the vicinity of any existing UG have already been handed over, it becomes very difficult to find a site for establishing CFE operations. Obtaining private land for such facilities is complex and expensive. The distance-related rule does not apply to those essential oil producing enterprises operating without using firewood extracted from the forests.

Over time, conflicting decisions have been taken by the MFE, ${ }^{7}$ Commission on Investigation of Abuse of Authority, ${ }^{8}$ the Supreme Court of Nepal ${ }^{9}$ and the Industrial Promotion Board ${ }^{10}$ on this issue. After several rounds of consultations and meetings with the private sector and other relevant stakeholders, the Ministry of Industry published a Gazette notification in 2014 to define the distance between forest area and enterprises based on the type of forest-based enterprises (see Table 5).

These distance-related measures also apply to those enterprises that were established before the date of this Gazette notification. Despite this Gazette notification, there remains considerable confusion due

7 The Ministry of Forest and Soil Conservation made a decision on 11 November 2007 to apply a $2 \mathrm{~km}$ distance in the Terai and $1 \mathrm{~km}$ distance in the Middle Hills.

8 The CIAA has given an order to apply $5 \mathrm{~km}$ distance in the Terai and $3 \mathrm{~km}$ distance in the Middle Hills.

9 The Supreme Court of Nepal made a decision to apply $2 \mathrm{~km}$ distance across the country during the establishment of any forest-based enterprise.

10 As per Sections 18 and 19 of the 2017 Industrial Enterprise Act (2017), the Industrial Promotion Board is the relevant body for recommending to the government the removal of any barriers related to enterprise development. 
to the lack of a common understanding between government agencies and forest-based entrepreneurs. The Gazette notification sets out that the above-mentioned distance measures will not be applied to enterprises operating within the Kathmandu valley and those falling within the jurisdictional areas of the district headquarters and municipalities. During the state restructuring process based on the new constitution, a significant number of areas previously recognized as Village Development Committees (VDCs) have been newly converted into rural municipalities. Therefore, according to the Gazette notification, the distance-related measures will not apply to enterprises operating in such new rural municipalities. In this regard, government agencies have argued that the distance-related measures should, in fact, apply to enterprises functioning in the jurisdictional areas of the newly declared municipalities because these areas were previously rural areas within VDCs at the time of the notification. Nearly of all the 12 CFEs in this study were established before this Gazette notification. Five out of the 12 CFEs have not formally registered because of the distance rule. For example, the Chisapani Community Herbal Industry is not registered but continues to operate. An additional CFE has found its growth potential stifled due to the distance rule; two other CFEs have specifically been unable to build infrastructure to support their enterprise activities.

Table 5. Distance-related rules for forest-based enterprises

\begin{tabular}{|c|c|c|c|}
\hline \multirow{2}{*}{ S.N. } & \multirow{2}{*}{ Type of enterprise } & \multicolumn{2}{|c|}{$\begin{array}{c}\text { Distance between forest area and enterprises in } \\
\text { various geographical regions (km) }\end{array}$} \\
\hline & & High and Mid-Hill & Chure, Inner Terai and Terai \\
\hline 1 & Furniture & & \\
\hline 1.1 & Cottage enterprises having up to 18 " log cutter & 0.5 & 0.5 \\
\hline 1.2 & $\begin{array}{l}\text { Small and medium industry having } 18 "-35 " \\
\log \text { cutter }\end{array}$ & 0.5 & 1 \\
\hline 2 & $\begin{array}{l}\text { All types of industry having } 36 \text { " or larger } \\
\text { than this size of log cutter (including } \\
\text { sawmill) }\end{array}$ & 1.5 & 3 \\
\hline 3 & Veneer industry & 1 & 3 \\
\hline 4 & Timber and firewood based industries & 1 & 3 \\
\hline 5 & Acacia catechu based industry & 1 & 3 \\
\hline 6 & NTFP processing enterprise & 0.5 & 1 \\
\hline 7 & $\begin{array}{l}\text { Enterprise established jointly by CFUGs } \\
\text { and private sector }\end{array}$ & 0.25 & 1 \\
\hline
\end{tabular}

Source: GoN (2014)

Furthermore, there is the problem that distance-related measures rely on a particular definition of "forest area". The second amendment in 2016 of the 1993 Forest Act defines 'forest area' broadly as roads, ponds, lakes, grazing and pasture lands, snow lands, wetlands, rivers, streams, riverbeds and public lands. As such, this substantially decreases the likelihood of identifying potential areas for forest-based enterprises.

\subsection{Transportation and export promotion}

Obtaining transport and export permissions pose an onerous burden on CFEs depending on the type of product involved. The 1993 Forest Act and 1995 Forest Regulations, together with additional directives, ${ }^{11}$ set out various stipulations for forest-based enterprises regarding the transportation of raw materials from specific types of forests, as well as for processed and semi-processed products. Ultimately, it is the DFO who holds the authority, based on documents provided, to provide a release

11 Some of these directives are 2007 Resin Collection (Procedure) Directive, 2016 Directive on Sales and Distribution of Forest Products from Community Forests, and 2017 Directive on Sales and Distribution of Forest Products from Government-Managed Forests. 
order to transport timber from all types of forests including community and private forests. Similarly, the DFO holds the authority to provide a release order to traders for the transport of herbs and NTFPs from one district to another district in order to supply raw materials to forest-based enterprises. After obtaining the DFO's release order, the traders have to pay royalties and all applicable taxes to the local communities (such as CFUGs) and government agencies based on the legal requirements. As a result of recent directives on timber and NTFPs, a newly required sealing system has made it easier for traders to have the seal checked only once because government officers only have the authority to open it at the starting and end points. ${ }^{12}$ There is, however, no proper legality tracing in each chain of custody for Nepal's forest-based products.

Despite these attempts to clarify transportation requirements, overlapping jurisdictional authorities between government agencies (central and local), police offices, tax offices and forestry offices has resulted in different types of obstacles during forest product transportation be it in the name of taxes, packaging materials, quantity, invoices or otherwise.

\subsection{Environmental measures and quality standards}

There are a number of environmental measures and quality standards that forest-based enterprises need to comply with in Nepal.

\subsubsection{Environmental measures for forest-based enterprises}

CFEs need to comply with environmental measures and standards during their registration and operation, including in the collection of raw materials from the forests. The main objective behind the Initial Environmental Examination (IEE) and Environmental Impact Assessment (EIA) is to conserve the environment and biodiversity. Annexes 1 and 2 of the 1997 Environmental Protection Regulation define various threshold options (see Table 6) for the preparation of IEEs and/or EIAs. Depending on the type, volume and location of an enterprise, these options set out whether an IEE or EIA will need to be prepared. ${ }^{13}$

However, due to IEE/EIA requirements imposed on the collection of even very small amounts of raw materials, CFEs face unduly burdensome procedural complexities in order to finalize the approval processes related to environmental measures. Therefore, forest-based entrepreneurs have advocated the revision of Annexes 1 and 2 of the 1997 Environmental Protection Regulation because the thresholds are defined according to different government decisions made at different times.

\subsubsection{Quality standards}

While Nepal has not developed specific quality standards for goods or products from forest-based enterprises, the 1967 Food Act and the 1998 Consumer Protection Act do provide a regulatory basis for maintaining the quality of food products and other commodities. The main objective of the 1967 Food Act is to prevent any undesirable adulteration of food or subtraction or extraction of any natural quality or utility, and maintain proper standards of food for public health. ${ }^{14}$ Similarly, the aim of the 1998 Consumer Protection Act is to protect consumers from irregularities concerning the quality, quantity and prices of consumer goods and/or services. Therefore, CFEs need to comply with the regulatory provisions concerning quality standards. However, due to the lack of laboratory testing facilities and

12 Chapter 14 of 2017 Directive on Sales and Distribution of Forest Products from Government-Managed Forests.

13 Section 3 of the 1997 Environmental Protection Act. The definition of 48 roots and shoots, 25 barks, 30 leafs/branches, 16 flowers, 66 fruits and seeds, 21 seedlings and 8 resin/gum related herbs is provided in Annex 3 of the 1995 Forest Regulations. NTFPs related to 26 plant species are defined in the Annex 6 of the 1995 Forest Regulation.

14 Preamble of the 1967 Food Act. 
government services at the local level, it is expensive to obtain a quality standard certificate from the relevant central government department. As the Bishasaya Community Wood Apple and Fruit Processing Industry management body complained, "Since our product is eventually consumed by people, it has to have a stamp of approval from the Government's Department of Food Technology and Quality Control whose offices are located quite far away from where our CFE is located. This is very inconvenient and not to mention, expensive travel. Also, the results from the various tests they conduct are not available for weeks, sometimes even months!"

Table 6. IEE/EIA requirement in Nepal's forestry sector

\begin{tabular}{lll}
\hline S.N. & IEE requirement(s) & EIA requirement(s) ${ }^{\mathrm{a}}$ \\
\hline 1. & $\begin{array}{l}\text { Paper enterprises that produce 100 tons paper } \\
\text { per day (except cottage enterprises) }\end{array}$ & $\begin{array}{l}\text { Establishment of resin, rubber, plywood, pulp and } \\
\text { paper enterprise within 1 km distance from forest } \\
\text { areas }\end{array}$ \\
\hline 2. & $\begin{array}{l}\text { Annual collection of 5-50 ton roots from the } \\
\text { forest }\end{array}$ & $\begin{array}{l}\text { Annual collection of more than } 50 \text { ton roots from the } \\
\text { forest }\end{array}$ \\
\hline 3. & $\begin{array}{l}\text { Annual collection of 10-100 ton bark from } \\
\text { the forest }\end{array}$ & $\begin{array}{l}\text { Annual collection of more than } 100 \text { ton bark from the } \\
\text { forest }\end{array}$ \\
\hline 4. & $\begin{array}{l}\text { Annual collection of 5-50 tons forest } \\
\text { products concerning those species which } \\
\text { have been banned for export without } \\
\text { processing }\end{array}$ & $\begin{array}{l}\text { Annual collection of more than } 50 \text { ton forest products } \\
\text { per year concerning those species which have been } \\
\text { banned for export without processing }\end{array}$ \\
\hline 5. & $\begin{array}{l}\text { Annual collection of 5-100 ton of forest } \\
\text { products other than timber }\end{array}$ & $\begin{array}{l}\text { Annual collection of more than } 100 \text { ton of forest } \\
\text { products other than timber }\end{array}$ \\
\hline 6. & $\begin{array}{l}\text { Establishment of herbs and NTFPs } \\
\text { processing center }\end{array}$ & $\begin{array}{l}\text { Larger-scale commercial and industrial processing of } \\
\text { herbs and NTFPs }\end{array}$ \\
\hline 7. & $\begin{array}{l}\text { Annual collection of more than 5 tons resin } \\
\text { per district }\end{array}$ & $\begin{array}{l}\text { Sawmill for the processing of more than 50,000 cubic } \\
\text { feet timber annually }\end{array}$ \\
\hline
\end{tabular}

Notes:

a EIAs are required for commercial and industrial processing operating at a larger production scale.

Source: Environmental Protection Regulation (1997)

\subsection{Taxes, royalties, loan and subsidies}

While there are a number of tax-based incentives for establishing CFEs, the taxes at both the central and local level on some products, such as high-value timber, can be both contradictory and burdensome (Baral et al. 2016). The revised 2017 Industrial Enterprise Act has a number of tax-related incentives that include:

- income tax exemption for all types of micro-enterprises including forest-based enterprises;

- $20 \%$ income tax exemption for production-oriented enterprises;

- $25 \%$ annual income tax exemption to those enterprises that have more than $50 \%$ women, Dalits (oppressed group at bottom of caste system), and employees with special needs (physical/mental);

- $25 \%$ income tax exemption to those enterprises that export all their products;

- additional tax incentives for women-led enterprises.

Nepal's 2002 Income Tax Act has made provisions to exempt income taxes for forest-based cooperatives. Annexes 2 and 6 of the 1995 Forest Regulations have set out the royalty rates for various herbs and NTFPs. The royalties for the majority of forest products are largely accepted as appropriate, although some confusion exists because royalty rates for the same species can differ in different documents, thereby creating complexities in obtaining transport release orders.

When it comes to export of forest-based products, the actual customs rate is not aligned with the objectives set out in the 2015 Trade Policy. Nepal's Trade Policy has significant provisions for 
promoting export of processed commodities from forest-based enterprises. The policy has listed MAPs, essential oils, Nepali handmade paper and forest product based handicrafts as "high potential commodities" for export. Similarly, the 2015 Cash Incentives Procedure has also made provisions to provide 1-2 per cent cash for those who export commodities from forest-based enterprises. However, the export customs rate for forest-based products is very high (up to $200 \%$ ), ${ }^{15}$ presenting a significant disincentive to traders.

In terms of credit mechanisms for forest-based enterprises, the 2017 Bank and Financial Institutions Act (section 47) has made a provision for Nepal's banks or financial institutions to provide loans to low income/poor families, as well as households in the country's remote areas, for their economic upliftment. For this purpose, the Nepal Rastra Bank (the central bank), has the authority to give orders to the banks and/or financial institutions that compel them to disburse loans to such poor families to establish enterprises, particularly those based on forest and agriculture. However, in reality, there is significant reluctance among banking institutions to issue such loans. Moreover, procedural complexities, such as collateral requirements, pose additional problems. Since CFUGs do not formally own their forestland, they have no opportunity to utilize this asset for collateral purposes. The 2017 Industrial Enterprise Act has also set out a provision to provide subsidy or seed grants through the Micro, Cottage and Small Enterprise Development Fund for use in in remote areas. ${ }^{16}$ In practice, households from marginalized or remote areas are least able to create a business proposal and approach banks.

152002 Income Tax Act.

16 Sec. 27 of the 2017 Industrial Enterprise Act. 


\section{Non-regulatory context for community- managed forest enterprises}

In addition to the policy and legal context, an important set of factors related largely to the internal governance, organization and capabilities of CFEs plays a central role in their development. Among these, the way in which CFEs are managed as a sub-unit of CBFM UGs continues to be an area of experimentation. How this relationship is structured has an important bearing on a number of key issues related to entrepreneurial scope, autonomy, profitability, financing and technology. One important external factor is the support provided by FECOFUN, the national CF federation.

\subsection{Governance and goals of community-managed forest enterprises}

Any type of investment source will examine how the CFE is governed in order to understand its capabilities and trustworthiness. At the internal level, there are two main ways of governing CFEs: the enterprise can lead the UG in developing its business, or the UG can lead the CFE. Nearly always it is the former, although both modes have their merits and disadvantages (Rai et al. 2016). In a number of cases, a consortium of UGs collectively establishes a CFE to pool resources and capabilities by creating a specialized governance structure for management purposes. However, the ability to address economies of scale in this way are often limited, due to institutional or geographical factors (Paudel et al. 2018).

In the $12 \mathrm{CFEs}$ studied, the enterprise was managed by a separately established UG management or sub-committee comprised of members of the UG executive committee. Typically, a manager is appointed to run the CFE. In contrast to forestry enterprises run by the private sector, the principles that are central to a UG's objectives have a significant bearing on how the CFE is operated. These principles include conservation and sustainable use of the forest or livelihoods and employment, with a pro-poor or gender-equitable orientation. The direct welfare benefits to the UG members are often significant. CFEs are a platform to promote social equity, with employment for the poor the most important goal (Subedi et al. 2002; Lamsal et al. 2017). In a study of three CFEs in Dolakha, the income of households increased through employment by $11 \%$ or more (Acharya 2005). The majority of participants in CFEs were the poor to very poor but, interestingly, gender discrimination was found within their wage structure.

This orientation means that the CFE may be making a gross profit (covering wages, running expenses, raw material costs, technology costs etc.), but not necessarily a net profit for distribution to the UG(s). In fact, since many CFEs operate with this social welfare orientation, monetarily calculating the costs and benefits is a complex process. Since the CFE financial management is dependent on the nature of the relationship between the CFE and its parent body (the UG), the UG executive committee both supports the CFE but also financially benefits from it.

As the manager of the Chisapani CFUG explained, "We didn't establish this enterprise to make a profit. Our main goal was to create employment for very poor women.... This has helped to conserve forests as they no longer need to harvest from the CFUG illegally." The CFE was able to provide employment to 65 women organized into different groups to produce essential oils. In addition, the CFUG allocated some land to a private institution to raise the plants needed for essential oils. Women from the CFUG households were able to either work on their own plots or work for wages in the private firm's plot. Over 12,000 households, as CFUG members, were beneficiaries of this enterprise. Similarly, in the Tamakoshi Resin and Turpentine Industry, dozens of local CFUG members were employed to carry the tapped resin to collection centers. Contrary to some CFEs discussed in the literature, many of the studied CFEs paid equal wages to men and women, such as in the Bishasaya 
Community Wood Apple Juice and Fruit Processing Industry. Such employment dynamics prevailed in CFEs, for example, in paper production in Dolakha, wood apple juice production in Nawalparasi, ecotourism in Chitwan, and biobriquette production in Sindhupalchowk. As a participant from Bishasaya Industry proclaimed, "We don't mind bearing some losses from the enterprise because it is providing employment benefit to the poor members in the community. We can compensate the losses from other sources." In such cases, the losses are covered by the funds of the primary UG which has other sources of income.

Beyond local employment, there are other types of benefits that UG members receive, be it in the form of cheaper services or materials, or support for adapting to changes in local production conditions. As the case of Gobardiha Wood and Furniture Industry illustrates, members no longer have to buy sawn timber or furniture from the market; rather, they get their logs sawn at the CFE creating savings while generating enterprise income. In addition to low-cost sawing, Gobardiha is able to minimize the timber consumption rate. The extra timber produced through saving waste means another household can be supplied with timber at a low cost, including those poor households who need small quantities for a bed or casement. In some cases, such as in Bhagwati Herbs Processing Industry, the start of the essential oil enterprise was vital after the CFUG was converted into a buffer zone next to Banke National Park. Households had to abandon their traditional crop farming and took up plant cultivation for essential oils. This cultivated area is increasing annually, leading to calls to expand processing capacity.

In nearly all cases, the UG receives some type of financial benefit from the CFEs. At times, this comes in the form of dividends or profits from the CFEs. This was the case for the wood apple industry in Nawalparasi, biobriquette industry in Sindhupalchok, ecotourism enterprise in Chitwan and the essential oil industry in Banke. Alternatively, CFEs pay a royalty to the UG. For example, the resin and turpentine CFE paid a royalty of NPR 900 per quintal for the 160 quintal of resin collected in 2016. In the Chisapani Community Herbal Industry, the CFUG charged community members and private companies (near or far) NPR 1,000 per lot for processing in its plant. The Baghmara BZUG was able to obtain license fees of more than NPR 500 per entry for elephants carrying tourists into the park. Kankali BZUG received entrance fees for its picnic spot and swimming pool. Such CFUG or BZUG funds, in turn, were used according to the national CF guidelines for forest conservation and development activities; income-generating activities for the poor; skill training; and infrastructure for health, education and drinking water.

It is perhaps because they are more welfare- than profit-oriented that only four (Baghmara BZCF, Kankali BZCF, Chisapani Community Herbal Industry and Everest Gateway Herbs) of the 12 CFEs reported net profits in the year 2015/16, while the remaining CFEs said they were either operating at break-even or loss. The ability to generate net profits is not necessarily a function of longevity. Some, such as Chaubas Bhumlu, have had many ups and downs over their lifetime. In the case of the newly formed Binayi Organic Manure Enterprise, the CFUG was compensating for the enterprise's loss by injecting funds from the core $\mathrm{CF}$ fund as part of the startup process.

To achieve its multiple goals, the CFE pursues business practices that enable it to generate employment, profit and overall prosperity for UG members. The CFE management body is responsible for coordinating with the UG executive body, managing production work, overseeing market sales, conducting the annual general assembly meeting and carrying out audits of financial transactions. Typically, the management committee composition is decided by the UG executive committee (based on gender, poverty status and ethnicity criteria). This can possibly present a risk whereby individuals are selected for the sub-committee who do not necessarily have entrepreneurial or business management capabilities and experience. For example, a member of the Chaubas Bhumlu Community Sawmill sub-committee said, "When the sub-committee was formed, one of the requirements that had to be fulfilled was equal representation of men and women. As a result, we have four men and four women in the sub-committee. The criteria for the selection of these individuals was about representativeness rather than having the skills to operate an enterprise." 
CFEs, as a sub-unit of the UG, can be encumbered by the lack of autonomy to take business decisions independently. All ultimate authority over investment, management and benefit-sharing is held by the UG executive committee. As a management team member of the Tamakoshi Resin and Turpentine Industry stated: "It is ideal to have representation and engagement of all the socioeconomic groups in the CFEs, but when we come to implementation, it is only a few in the lead. This makes collective decision making rather complicated and unsuitable for running a market-oriented enterprise." Even simple decisions, therefore, can become cumbersome: for example, in Kankali BZCF, any purchase required the sub-committee to file a written request to the Kankali BZ executive committee for approval.

The practice of having to change members of the sub-committee including the chairperson (every 2-3 years) is deeply engrained in the CF governance approach. Such frequent leadership changes can pose problems for longer-term business planning. Additionally, all too often, UG members tend to choose a chairperson more for political affiliation and social image as opposed to capability or qualifications. Similarly, collective decision-making, although democratic in nature, can be out of sync with the timing of business decisions that need to be made quickly and in response to changing circumstances.

At times, these arrangements have been altogether skirted around. Take the case of Deodhunga Multipurpose Cooperative where UG members explained their frustration: "At the moment, although the CFE is established under the name of an individual who is a member of the CFUG, the enterprise is solely owned and operated by a private entity. He does all the work: collects the herbs, carries out the oil distillation process, supplies it to the buyer(s), and keeps the profit for himself. This has irked the locals because they have not received any benefit from this CFE, even though it is established in the CFUG's land and uses the CFUG's resources."

Given the typically low profit margins, members of sub-committees work as volunteers (as do UG executive committee members). This can result in a lack of incentives to sustainably build the enterprise's administrative, technical or marketing capabilities. That said, there are hired staff with specific responsibilities for harvesting raw materials, running machinery or carrying out sales. All in all, the operational mandates of a CFE business does not always easily align with the UG's approach.

A consortium of UGs are often created to address limitations of a small forest area with raw material constraints, or to generate pooled investment capital or labor. Such an approach brings into play more organized bargaining power when dealing with regulatory issues or specific government officials. In particular, when banks and financial institutions are not willing to issue loans (in the absence of secure collateral), then funds are often borrowed by the CFE from one or more CFUGs in a negotiated agreement. At times, it is a geographical need that leads to a mutually beneficial partnership through resource pooling or sharing. For example, the Baghmara BZCF has partnered with neighboring Chitrasena BZCF. These UGs are divided by a river where visitors can take boatrides to see the forests with rich biodiversity, such as crocodiles. The ticket sale revenue is equally distributed between these two UGs.

At times, such partnerships have not proven to be productive. In the case of Hanspokhari Nepali Handmade Lokta Paper Enterprise set up in 2010 under the Hanspokhari Krishi Sahakari (Cooperative) in Bhojpur district, there was fierce debate about where to set it up (Rai et al. 2016). In the end, two CFUGs were selected: Nayakharka and Hattimare CFUGs, of which the former was very active and the latter passive. As a result of confusion about management responsibilities between the cooperative (that formally received the financial benefits) and the enterprise, and also because of misunderstanding between the two CFUGs, the enterprise was unable to produce the quality and quantity of paper needed to stay afloat financially. Ultimately, with no balance fund, it was wellwishers who supported the CFE. Meanwhile, other CFUGs in the VDC with lokta paper resources sold it to outside enterprises. 
As an alternative, some CFEs have developed partnerships with an I/NGO or a private sector entity in order to mobilize asset capital, gain technological access or target specific markets. Bringing into play a stronger entrepreneurial spirit in this manner helps the CFE overcome lack of experience and knowledge. Very often, when the I/NGO offers startup capital to a CFE that is established as a company, this is converted into shares for poor households through a well-established community wealth-ranking approach. There may also be other shareholders, such as CFUG institutional shares, individual UG members as private investors, as well as some forest sector private companies. Such approaches are found at Gobardiha and Everest Gateway. It is the UG executive committee or consortium of CFUGs that determines these allocations, profit-sharing and monitoring mechanisms.

In terms of such external engagement, there is all too often UG resistance against any authoritative role for the private sector in a CFE. UGs very often vote to prevent the private sector from holding any controlling position in order to retain full control (Rai et al. 2016). This is because they believe they have invested considerable time and money in building up their institution as well as forests and resources, and therefore should be solely able to lead the CFE activities and determine benefit-sharing. There was fear that the private sector would undermine the governance work that had been built up through years of community engagement. This was very evident in Kankali BZUG who explained that, "When our EC made a proposal of allowing a private sector company to operate amusement items, such as rotating swings, within the existing picnic spot run by the UG during the general assembly meeting, there was a strong opposition to the private sector participation proposal. The management committee had to withdraw the proposal without any further discussion."

Similarly, at the Bhagwati Herbs Processing Industry, the community refused having a private sector entity taking over production because it could not then process the products at concessional rates for the community. At the Gobardiha sawmill, despite problems, the viewpoint was that, "We know that if we hand this over to a private company, it can overcome all these regulatory barriers and start operating without hurdles by any means. ... But the community will start suffering due to higher prices of services and the forest quality will be compromised." Their view was that, if the CFE runs into trouble, and a local private company emerges from the community itself, that option could be considered.

Predictably, the private sector itself is wary of becoming involved with CFEs due to the distance rule, or because of the high transaction costs in working with a large group of people ultimately with insufficient profit margins. As noted earlier, in some cases, as in Chisapani CFUG, a private company collaborated with the CFUG on investment, employment and land leasing. In exchange for investing NPR 500,000 (about US\$5000) for processing plant construction, the company was able to lease the CFUG's land for essential oil cultivation, while also paying daily wages to local women to work on this land.

\subsection{Role of Federation of Community Forestry Users, Nepal}

In the global literature on LCF, the presence of a federation or network that supports the LCF interests is critical to its success (Pasiecznik et al. 2015). In Nepal, FECOFUN, the national umbrella organization of CFUGs, has played a pivotal role in establishing and promoting CFEs to bolster livelihoods, social equity and employment. FECOFUN remains Nepal's largest civil society organization. In the early 2010s, it introduced the motto "One Community Forest, One Enterprise." At its Fifth General Assembly in 2014, one of its central program mandates was to address unemployment issues in rural Nepal through CFEs. Among its various campaigns in support of CFEs, it has pushed for provisions that allow the legal registration of forest-based enterprises under community or UG ownership (in the way the 2017 Industrial Enterprises Act now recognizes). In addition, it has lobbied for giving preferential status to CFUGs as business entities that should not be charged value-added 
tax or other forms of taxes. Most important of all, it has campaigned to change the distance-related provisions and environmental standards (EIA/IEE requirements) that pose major obstacles for CFE functionality. This is in addition to its regular work in support of governance improvements including on gender equity and social inclusion.

FECOFUN has argued for creating sustained investment by encouraging CFUG bodies to invest in CFEs and create a community enterprise fund at the national level. At a more fundamental level, FECOFUN has campaigned for stronger tenure security so that the devolution of forest rights can give CFUGs greater autonomy. At times, FECOFUN has taken a strong position against private sector engagement, which can work against the long-term capabilities of CFEs.

Within the Forest Farm Facility's initiatives in Nepal, FECOFUN has been working together with IUCN to analyze blocks to CFE growth and establish a platform for sharing experiences and lessons. Additionally, FECOFUN has been involved in CFE study programs for CFUGs from other countries, such as Myanmar. Certainly, FECOFUN is well positioned to take up additional needs such as promoting joint processing facilities or collection centers for CFE products should the lesson on the importance of aggregation take stronger hold.

\subsection{Raw material availability}

A CFE can only access raw materials above what is needed to meet their UG member household needs. All CFUGs provide basic forest products under concessional conditions to the poor. The literature on Nepal's CFEs indicates that unsustainable practices for resource harvesting (especially of NTFPs) are prevalent. Since harvesters are able to collect NTFPs in both CFUG forests and government-managed forests (which are less well monitored and patrolled), it is assumed that there has not been a significant move to cultivate NTFPs. Since there are no regulatory requirements that the CFUG's OP address NTFP or other resource management requirements, there are no set limits for harvesting levels. Even so, the CFE's need to secure a reliable raw material supply has meant that they have autonomously developed plans to ensure this does not become a limiting factor. In practice, they monitor the situation through the forest inventory, create strict sanctions against premature harvesting and establish their own plantations (Acharya 2013). Most of the studied CFEs have taken steps to address the problems posed by resource constraints.

That said, there is a lack of comprehensive knowledge on species identification, cultivation practices and sustainable harvesting protocols among UGs. As a result, CFEs can quickly enter into difficulties. Take the case of Deodhunga Multipurpose Cooperative, where essential oil is extracted from fragrant wintergreen (Gaultheria fragrantissima, known locally as dhasingare and machino). When asked about the state of this plant, a CFE management committee member said, "About a decade back, the enterprise was operational for almost the entire year. At present, the enterprise operates only for two to three months in a year. Machino has declined significantly when compared to the times when the enterprise first started. This herb is not readily available anymore, anywhere because of overexploitation. This is seriously affecting our business."

Similarly, at Everest Gateway Herbs, the lokta plant used for producing handmade paper had to be abandoned because of the alarming rate at which it had been harvested. Lokta was harvested more aggressively than argheli (Daphne edgeworthia) because lokta handmade paper was more profitable. As the Everest Gateway management body indicated: "Private enterprises or even individuals lure the locals to harvest plants used for making paper regardless of their maturity levels. This has led to unsustainable and haphazard extraction of the lokta and argheli plants in the region." In the end, this CFE planted over 1200 lokta saplings in 2014's monsoon season; it is anticipated that this, together with improved natural regeneration, will permit use of lokta again. Similarly, at Bishasaya Community Wood Apple and Fruit Processing Industry, local people have planted 500 wood apple seedlings over 
its 191 hectares. While this is a positive step, the risks involved in transforming a multi-species natural forest into a wood apple monoculture forest have yet to be assessed.

Varied sustainable management approaches are being adopted within specific CFEs. At Chisapani Community Herbal Industry, plantations are being established by growing seedlings in its own plant nursery. Scientific forest management has been adopted to ensure an adequate supply of raw materials, while allowing regeneration of valuable sal (Shorea robusta) trees. The Gobardiha Wood and Furniture Industry sought to reduce sawing wastage to minimize felling pressure on its CF. Moreover, this CFE also recognizes the potential to enhance timber volumes by using scientific forest management, but so far, this has not been possible. The Tamakoshi Resin and Turpentine Industry has made some technical adjustments in order to promote resource sustainability. The results of this will become evident over the long term. In some CFEs, waste materials were being used. Take the case of biobriquettes in Piyukharka or organic manure in Binayi where alien invasive species have been used to create their product.

In Chitwan, both the Baghmara and Kankali BZUGs reinvested revenues it had collected from forest conservation. In Baghmara, for example, $20 \%$ of their annual revenue of NPR 2 crores (about US\$200,000) goes toward conservation-related activities while also investing heavily in education (both primary and secondary schools).

\subsection{Skilled human resources}

There are a number of reasons why CFEs face a growing shortage of skilled workers. Firstly, migration from rural areas to cities within Nepal and emigration to foreign countries for employment has become an extremely common phenomenon. The significance of emigration is clearly evident in the fact that remittances constituted 27.7\% of Nepal's gross domestic product in 2014/15 (GoN 2016). In 2014/15, more than $70 \%$ of those who emigrated from Nepal belonged to the 15-34 years age group followed by those in the 35-54 years age group (14\%) (CBS and UNFPA 2014). Secondly, the lack of a clear and established incentive structure (such as uncertainties pertaining to salaries and untimely salary payment) in CFEs makes it difficult to attract skilled staff. Thirdly, skill training for forest-based enterprises is not easily available.

This problem of finding skilled staff is prevalent and was experienced by all 12 CFEs under study. For example, Kankali BZCF has had to limit some of its services, such as the swimming pool and mini zoo because of a lack of skilled staff. To fill this void, some CFEs (mostly timber based) hire foreign workers (usually from India) to work on a contractual basis. For Gobardiha sawmill, this was only on an 'as needed' basis, since it is closed for a number of months each year.

\subsection{Access to financing}

Policy support for attracting sustainable finance for CFEs is largely ambiguous (Acharya 2013). There are a wide range of possible funding sources: donor or NGO investment, government programs, microfinance, bank loans, CBFM institutions and the private sector. Beyond donor or NGO support, UGs are often at a disadvantage in applying for bank loans because when they have been established as a company under the name of one or more $\mathrm{CF}$ members only collateral from the named individual can be used. However, the risk to the individual CF member precludes such a possibility.

The GoN also allocates a certain amount of money as public grants to be invested in forest enterprises either through projects or directly through the DFO. However, there is a lack of clarity over the amount annually allocated, and on how to access public finance. This leads to a public perception that these funds can be used in a discretionary fashion. As such, CFEs are forced to seek other means of financing. For instance, the Chaubas Bhumlu Community Sawmill and Kankali BZUG sought alternative sources of financing in the form of loans from their respective neighboring UGs. 
Another form of financing that CFEs are increasingly seeking is through private sector investment. The Chaubas Bhumlu Community Sawmill has become well known because of its many ups and downs (Timsina 2005). Originally established in 1995, and supported by the Nepal Australia Forestry Project, it was managed by four CFUGs in the vicinity. However, due to a combination of legacy, business and governance challenges, it was closed down in 2012. Besides registration problems, the CFUG partnership led to disputes over responsibilities and benefit-sharing arrangements. Embezzlement of financial resources, corruption and skewed benefit distribution added to the issues. The extortionary demands of the Maoist insurgency generated further unforeseen challenges. Finally, in 2014, due to renewed efforts by the Australian Centre for International Agricultural Research, diagnosis of the problems led to the involvement of a private entrepreneur who paid a lump sum (NPR 211,000 or about US $\$ 21,100$ ) to the four CFUGs to operate the sawmill (irrespective of profit or loss). Having turned around its operations, it was functioning well through machinery and equipment upgrades. Four full-time and two part-time individuals were hired from Bhumlu. Members of the CFUGs had become more committed to managing their forests, "Our trees were growing old and we did not know what to do with them. They were deemed to be almost useless especially after the cessation of the sawmill. Now, with the sawmill up and running, this has given us avenues to utilize these resources that are aplenty in our villages. I, along with others in our villages, finally have an 'updated' purpose for managing these forests!" In mid-2019, however, the Community Sawmill faced another crisis when the private entrepreneur withdrew. Similarly, $20 \%$ of the shares of Everest Gateway Herbs are owned by a private investor.

\subsection{Entrepreneurial culture: Donors, business planning, development and profitability}

In the context of a country where entrepreneurial culture is still a relatively novel idea, the government and donors have played a critical role in jumpstarting CFEs through idea development, startup capital, provision of technology, training and capacity building, and creating partnerships and networks. While donor-based initiatives have played an important incubatory role through pilots, the support and incentives have also distorted market realities (Lamsal et al. 2017). This has prevented CFE management units from facing the questions of profitability and long-term viability until after donor support has ended.

Out of the 12 CFEs studied, it was found that 10 were established through the support of external agencies, such as DFOs, donor-funded projects and I/NGOs. They provided these CFEs with initial capital investment amounting to a total of NPR 5,769,965 (about USD\$ 57,700). At least two inferences can be drawn from this. Firstly, the CFEs were the direct result of the investors. The chairperson of Bishasaya Community Wood Apple and Fruit Processing Industry said, "Our CF had plenty of wood apples but other than the locals consuming them, we were unaware of doing anything with them from a business point of view. We were approached by the MSFP which was a multi-donorfunded project to establish a wood apple enterprise producing bottled wood apple juice. We received NPR 85,715 (about US $\$ 857$ ) from the project to buy some machinery in addition to carrying out some training. That's how our CFE came into existence. Before they approached us, we didn't know anything about such an enterprise whatsoever!" Secondly, the CFUGs did not have the required capital to start such an enterprise. Later, as the CFE became operational, they encountered other problems: "Our product is based on a fruit that can be harvested only once a year. Therefore, our production is limited to a maximum of two months per year. The rest of the year, we do not produce anything. This seasonal aspect of production is not allowing us to practice optimal scales of production which is impacting our finances."

At times, donor involvement without sufficient research on product development has led to oversupply. In one CFE, the manager complained that, "I have no problems with donors wanting to help us. But what my CFUG has a problem with is that we have an enterprise producing the identical product 
that eight other CFUGs in the vicinity are also producing. This has led to supply exceeding demand meaning we cannot fetch buyers, or even if we do, we are forced to sell our products at a much cheaper rate. The donors need to study a little better before coming up with these projects because we as locals will say 'Yes' to an opportunity given that we cannot invest millions of rupees on machinery equipment or send our people for a skills development training on our own."

Most CFEs are run by communities or individuals with relatively inexperienced managerial and technical staff. As a result, they face significant competition from larger manufacturers in business negotiations, quality and pricing. Skills-based training provided by business development services focusing on forest-based enterprises are rarely organized by either the government or NGOs. Even basic knowledge of markets is often lacking. Take the example of Binayi Organic Manure Enterprise, which asserted that, "The challenge we now face is getting our products to the market. We have no idea how we can do that. We have packets of compost just lying around. Some private contractors came to us and recently bought about 100 packets at NPR 18 per packet. I came to know later that they were being sold in shops of Butwal, Narayangarh and even Kathmandu at NPR 100 per packet. If we can somehow establish a direct link with the buyers, we can make a lot more money for our community."

Understanding forecasts and demand scenarios is another area of weakness. In Piyukharka Biobriquette Industry, business plummeted as changes in electricity supply took hold. "In the post2015 earthquake scenario, the demand for our biobriquettes was very high. We were very happy to have met the demands and we kept up our production. However, the demand nosedived after mid2016, mainly because people could use electric heaters during winter after the (electricity) loadshedding problem in Kathmandu valley was resolved! Now we have all these biobriquettes and we have no idea what to do with them!"

It is unsurprising that CFEs often do not have the skills for comprehensive business planning. CFE business plans do not normally comprise comprehensive profit/loss and cash flow projections for multiple years. Therefore, it is not uncommon to see a period of decelerated growth in CFEs after an upward trend. Once profitable ecotourism CFEs such as Baghmara BZCF and Kankali BZCF Enterprise have not grown as expected. The concept of gradually investing in better equipment in order to increase profits is uncommon. Similarly, in the Gobardiha Wood and Furniture Industry, there is no consideration of how the waste or the sawdust by-product could be used for other products such as particleboard, wood pulp or mulch.

A lack of connectedness creates many difficulties in building an entrepreneurial culture. ANSAB has organized a number of projects and publications to build entrepreneurship in rural, natural resource dependent communities (see for example, ANSAB 2010).

\subsection{Technology}

While it is recognized that those CFEs that rely on traditional technologies and knowledge have a better chance of success (Subedi et al. 2002), they are unable to derive higher profit levels. Since most of the NTFPs are sold, domestically or internationally, in raw form, there is a very significant problem of value addition. A meta-analysis of donor work on forest-based value chains under the MSFP indicated that investing in technology, such as in the chiuri value chain, produced numerous positive multiplier effects including for profit and production capacity (Rytkönen 2016). While there is clearly a need for updated technology, this is one of the most prominent obstacles for all the 12 CFEs in order to improve value addition. Being able to process raw materials, meet environmental and quality standards, provide a product which generates greater value, and which minimizes waste often requires technology upgrades. 
Take the case of the Tamakoshi Resin and Turpentine Industry, processing the raw or unprocessed resin that is sold to buyers from Nepal and India would increase profits. Besides processing, technology improvements can reduce wastage or loss of quality at many stages. At Everest Gateway Herbs, handmade paper from lokta and argheli is currently sun dried. However, drying under unfavorable cloudy or rainy conditions damages the product. With suitable drying technology, this CFE could substantially expand its operational scale. Technology limitations also prevent Everest Gateway from making other products such as handbooks, calendars and lamp shades. In the Chisapani Community Herbal Industry, the level of essential oil that can be extracted from lemongrass, citronella and palmarosa is dependent on both their maturity at harvest and weather conditions. The chairperson of this enterprise indicated that, "We are aware of newer and advanced distillation plants that can help to avoid loss in the amount of essential oils that occurs due to unfavorable weather conditions. However, we do not have such technologies at our disposal for the time being."

At the moment, the Bishasaya Community Wood Apple and Fruit Processing Industry produces wood apple squash, a healthy beverage. However, as the chairperson of this CFE opined, "Ideally, we would like to manufacture 'ready-to-drink' wood apple juice as opposed to squash that needs to be mixed with water before it can be drunk. If we had the technology to manufacture 'ready-to-drink' juices, we are confident that our sales figures would go up exponentially. However, we do not have that. Technology makes a big difference.” In the case of both Chaubas Bhumlu Community Sawmill and Gobardiha Wood and Furniture Industry, which currently provide sawing and other wood processing services at their respective locations, they believe that they can increase their customer base if they had possession of a mobile sawmill. Given the hilly topography, CFEs could cater to people's needs wherever they are based.

Irrespective of capital availability, none of the 12 CFEs studied had invested much time toward research and development in order to upgrade their product-specific technologies. At the same time, there is not much government support for accessing knowledge about technology options and their cost implications. The lack of interest among community members in investing in new plants or additional upgrading could be the outcome of better investment opportunities in agriculture or in businesses with a more secure standing (i.e. did not have to deal with distance rule or registration problems). It was observed that communities preferred to ask for donor support rather than raise the capital independently. As an example, the biobriquette factory had recently received donor funding to replace an old building that had been damaged by the 2015 earthquake.

\subsection{Advertising, branding and certification}

Advertising, branding and certification, while important components of marketing products and services, are largely overlooked within the 12 CFEs studied. None of the CFEs aimed to differentiate their products from other existing competitors and thereby found it hard to establish a loyal customer base.

There are some positive contextual factors supporting the sales of Bishasaya's wood apple squash: the health benefits of wood apple are quite well-known, and Bishasaya's squash has been certified as safe for consumption by the Regional Office of the Department of Food Technology and Quality Control. Even so, the product has only been sold to locals and in a few surrounding shops. The company's brochure only provides information for visitors to the facility. A word-of-mouth marketing strategy has geographical limits and cannot help with product differentiation. Potential customers lack knowledge, and therefore trust, in the brand itself. There is a great opportunity to market this product in major cities like Kathmandu, Narayangarh, Butwal, Pokhara and Hetauda.

At Kankali BZCF, the local brochure only introduces the types of recreational activities available without any insights into the area's ecological richness. Both Kankali BZUG and Bhagwati CFUG, 
however, do draw upon radio announcements and TV commercials to highlight their products. Some develop links with dealers and customers through local and national-level fairs and expos.

Specifically on the issue of certification, such as with the Forest Stewardship Council (FSC), the costs involved are beyond the financial capabilities of most UGs. As the chairperson of Binayi Organic Manure Enterprise said, "It is perhaps true that our product would be better received in the markets especially in cities like Kathmandu and Pokhara if our product was from a FSC certified forest. It will undoubtedly help to establish a brand and a name for ourselves. However, the scale of our operation and that of most CFEs in Nepal are so small that the costs involved in acquiring the certification outstrip the revenues generated. Hence that is not an option, at least not for now." Group certification is an approach that was piloted by ANSAB together with FECOFUN in Bajhang and Dolakha districts among 21 CFUGs (managing about 14,000 ha) covering 24 different NTFPs (Subedi 2006). This group certificate was the first for NTFPs in Asia. FECOFUN worked as a Resource Manager to the CFUGs providing information on how to meet the certification requirements, and in turn monitored their activities. In this way, international standards for quality, product design, processing and documentation can be met. 


\section{Investment effects of community- managed forestry enterprises as social firms}

The long-term investment of effort and money by forest UGs in both crafting local forms of forest governance and regenerating local forests has paved the way for moving beyond meeting subsistence needs in the form of CFEs. This study shows that when CFEs are grafted onto Nepal's varied community forms of forest governance, there is a primary fidelity to the mission and values of the UG, even as they pursue entrepreneurial and profit-making goals. Since they are largely focused on addressing both livelihoods and social equity, as well as improving forest sustainability, they can best be called 'social firms.' As such, CFEs are oriented to provide a range of social welfare services to their community even as they attempt to generate net profits for distribution. UGs therefore view CFEs as a form of social impact investing.

As the findings from this study indicate, the momentum behind CFE growth was built by governmentled programs, donor-based initiatives and I/NGO projects working with local communities and the private sector. These enabling investments have served to provide seed grants, registration support, entrepreneurship development opportunities, and technology that formed the basic foundations for CFE startup. In doing so, however, the types of registration modalities available to CFEs to operate as a commercial entity were not designed to address the specific governance and ownership conditions of CFEs. Until the 2017 revision of the Industrial Enterprise Act, UGs had to register under the various existing legislative options available for formally setting up their enterprise, be it as a micro or small enterprise, cooperative or private limited company, each with their own tax obligations and incentives. These institutional modalities for registering their commercial operations did not match their legal status as a community-based institution without recognized land ownership rights and therefore collateral opportunities. As such, from the start, this limited their ability to access capital to launch their enterprise.

Ultimately, many CFEs chose to forego registration because the requirements were onerous and expensive. This, together with the various regulatory requirements set up by the forestry ministry to operate a CFE such as the distance rule, transport and export permits, environmental measures and quality standards, among others, additionally led to informality. Among these, the business risk incurred by the distance rule not only created a very clear disincentive to registration, but also prevented the private sector from working with CFEs.

Since the management structure of CFEs has remained firmly in the control of UG executive committees, given that they consider CFE development to be an outgrowth of their own long-term investment in local governance and forests, CFEs inevitably pursue the mandate set up by the UG parent body. As a result, the CFE infrequently prioritizes a range of social welfare or benefit goals over pure profitability. Employment, providing affordable services and savings to UG members, supporting a shift to different livelihood options, and improving forest conservation are among the benefits UGs provide. As a result, even though the UG receives financial benefit from the CFE (such as dividends, royalties, license fees or ticket revenues), the UG (or a well-wisher member) may also be providing funding support when and as needed to keep the CFE afloat.

Although asset investments are needed to incubate individual CFE business opportunities, it is the prevailing array of regulatory and non-regulatory factors that mitigates against CFEs generating net profits even though they may be able to create a cash flow that supports the expenses underlying various positive social impacts. As such, not many CFEs are able to create annual net profits, let alone growth, over time. Only those with a reliable customer base (as in ecotourism enterprises) or established markets (as with some essential oil or handmade paper companies) are able to weather the 
vagaries of building a CFE. Even when CFEs are able to navigate the regulatory complexities, their own internal limitations, be it on UG-CFE governance arrangement, raw material supply, technology, skilled staff or marketing, become obstacles to sustaining their enterprise.

While UGs creatively attempt to pool their local resources (capital or otherwise) in order to overcome prevailing limitations, in the end, it is their lack of overall connectedness that makes it difficult for them to build the necessary capacities to become commercially profitable or even create greater social impact. Building economies of scale through connecting with other CFEs can also help overcome certain limitations such as high transaction costs and weak bargaining power. Since the government's local agencies are unable to provide the services needed for training and capacity building or market analysis (especially as the transition to devolution of government takes place), the only other option is for FECOFUN or new locallevel FFPOs to fill this vacuum. Currently, FECOFUN is working with the Forest Farm Facility to build a platform whereby service provision can support business incubation and market development through aggregation. Since donor support can serve to distort the market realities that CFEs have to confront, such neutral service delivery organizations can enable CFEs to gain the expertise and knowledge needed to become successful. If tiered FFPOs are created, then an apex body could develop a coordinated market information system where data is made available to the CFE manager/committees in accordance with their informational needs in a timely and updated manner.

By prioritizing certain value chains and market development, enabling investments of this kind can create multiplier positive effects. If coupled with the government's enabling investment directed at steps required to clarify, simplify and harmonize the cumbersome registration processes and regulatory requirements, CFE establishment and growth can be efficiently streamlined. While the overall policy scenario is improving for CFEs, many of the strategic goals set out by the government have not yet been reflected within the legal frameworks that, in practice, govern forest management, industry and trade. The move in the recent 2017 Industrial Enterprise Act to legally recognize and prioritize UGs as forest entrepreneurs is a positive one that signals change in this direction. The 1993 Forest Act and 1995 Forest Regulations still need to be amended to reflect the priorities established for forest-based enterprises within the 2015 Forest Policy and 2015 Forest Sector Strategy.

Given this context, the private sector, that would clearly like to see a monetary return on investment, is wary of investing in CFEs as it poses considerable risks. Therefore, the probability of attracting asset investments outside of the UG's own resources remain slim. This is primarily related to the constraints of the policy and legal context in which CFE startup and development takes place, but also to do with working with a community-based governance arrangement. Even so, some private sector companies have entered into partnerships or contractual arrangements with CFEs such as in Chisapani Community Herbal Industry or Chaubas Bhumlu Community Sawmill. If regulatory obstacles can be minimized and streamlined, then the potentially high profit margins and low risk would bring considerable incentives into play for the private sector. Changing the risk equation in this fashion can cultivate optimism in the CFE sector.

Targeted enabling investments by the government, donors and I/NGOs can permit the CFE to graduate to the next step, from where diverse types of asset investments from a range of sources can be attracted. CFEs can begin to build a culture of trust around its operations and ability to deliver results. That said, it is evident that the relationship between the parent UG and the CFE management body remains a complicated one as the CFE seeks to meet both UG vision and mission while gaining momentum in an entrepreneurial direction. These are not atypical governance challenges for social firms creating multiple types of social and environmental benefits for their community.

There is widespread acknowledgment among CFUG members, CFE operators, government officials, civil society groups and the private sector that the full economic potential of the CFE sector in creating prosperity has been far from realized. By developing multi-stakeholder platforms for discussing how enabling and asset investment in Nepal should be layered and sequenced in time, multiple types of 
CFE growth pathways can be forged tailored to particular value chains and geographical contexts. Indeed, since CFEs are essentially social impact firms, they can draw lessons from the broader world of social impact investing. It is clear that social impact firms can have many orientations: blended strategies that strike a balance between obtaining lower returns in exchange for positive impact, market rate with impact, sector-focused in the form of enabling investments, and impact alpha (where high market returns are obtained because of the focus on social impact) (Greene 2015).

What is critical in understanding investment dynamics is the fact that, among the various types of LCF, it is the UG that is the primary investment partner; it has already invested in crafting its forest governance structure and regeneration of local forests with much time and collective effort. As such, because its social impact orientation stands front and center in its decision-making, the lessons from the global social impact investing experience provides guidance on the many options and pathways forward. 


\section{Conclusion: Community-managed enterprises for prosperity}

The objective of this study has been to understand the investment effects of forest rights devolution within Nepal's CFEs. Given the fact that the UG is the investment partner in CFEs, how do CFEs leverage the various types of enabling and asset investments needed to support startup, operation and profitability within the context of prevailing regulatory and non-regulatory factors? The analysis presented is based on both primary data from 12 selected CFEs, as well as secondary data from published, government, and gray literature.

The roots of CFEs lie in Nepal's forest rights devolution that began in the late 1980s, spawning various types of CBFM institutions. As these UG governance bodies worked to improve local forest governance and forest regeneration, the motivation to move beyond meeting subsistence needs led to the establishment of CFEs. Starting from the early 1990s, these were mainly created by CFUGs and to a lesser extent BZUGs. These forest governance institutions became the institutional bedrock for CFEs. Over the course of the first wave of CFE growth, covering a period of nearly 30 years, the state of CFEs has been a growing but unstable one: many are still functioning, some closed down after a few years, and new ones continue to be created. While it is difficult to obtain reliable estimates on the total number, a majority of these roughly 41,000 CFEs operate informally because of the constraints presented by the various laws governing registration for different types of commercial entities or the regulatory requirements for running a CFE. The complex regulatory environment for CFEs has been constituted through a series of punctuated developments in law and policy such that there is not only poor harmonization across them but also many bureaucratically driven permit-based restrictions and requirements that impose onerous burdens beyond the capabilities of most CFEs. Even so, it is estimated that about $30 \%$ of CFEs officially register as a business with the government, be it as an enterprise, cooperative or company.

Given the demand for NTFPs, particularly MAPs, for export to India, the government's forest ministry has developed policies to support the NTFP sector from the late 1980s onwards. By the late 2000s, trade and industrial policies also echoed the importance of NTFPs for improving Nepal's economic growth through expanding export-oriented trade. As such, roughly $60 \%$ of the Nepal's CFEs focus on NTFPs, particularly harvesting raw MAPs for sales to traders. Since this is a business sector in which harvesters have weak bargaining power and therefore receive low levels of remuneration, only the poor UG members engage in this activity. In parallel, the government's strong pro-conservation stance in the forest sector has been softening into one that acknowledges some form of timber production is necessary to stem the high levels of timber imports into Nepal. This changing orientation was reflected in the 2015 Forest Sector Strategy. It is anticipated that CFEs will increasingly be able to take advantage of this shift in policy perspective, bringing with it the higher value addition opportunities it potentially offers.

In terms of the internal factors affecting CFE development, our research showed that CFE management is under the direct control of the UG executive body with its attendant vision and mission. As such, this organizational structure makes CFEs predisposed toward supporting a broader notion of prosperity than solely profit-making. In supporting employment (particularly for the poor, disadvantaged and marginalized) and other forms of social welfare for UG members, the CFE's ability to deliver net profitability, let alone growth, is curtailed. Indeed, such an orientation means that even where there is negative cash flow, UG funds (or individual well-wisher members) may help keep the CFE financially afloat. 
Furthermore, this fidelity to the UG's vision results in their reluctance to relinquish their authority over the CFE to any private sector entity. Only when the CFE enters into difficult economic challenges does it begin to reflect on how a partnership with the private sector can help it recover its cash flow or profitability. Here too, there can be a preference for a locally known private sector partner with which it can effectively negotiate its requirements. Given this business orientation, there is a preference for asset investments that are either autonomously generated within the UG (or consortia) or that present minimal obligations in terms of adjusting decision-making power within the forest governance institution.

Certainly, this first phase of CFE development has been facilitated through a set of enabling investments. Ten of the 12 CFEs studied were started with the support of government, donor or I/ NGOs. These enabling investments provided capital to buy equipment and training opportunities, and facilitate local networks and partnerships to build capital, knowledge and aggregate resources. That said, of the four CFEs that were profitable, two were focused on ecotourism with startup funds from their own BZ executive body, and another two (on essential oil or handmade paper) with support from NGOs.

Now that new government momentum behind forest-based enterprises is gathering energy, the possibility of robust growth in this sector remains a distinct hope in Nepal. The key gaps and challenges in facilitating growth involve harmonizing and streamlining the regulatory frameworks for CFEs, as well as building sustainable forms of partnerships (with other UGs and private sector entities of various kinds) and financing for asset investments. Building model initiatives with good practices in prioritized value chains will set the groundwork for layering and sequencing enabling and asset investments. In this way, multiple pathways for social impact investing can be set into motion for generating prosperity in rural communities across Nepal's forested landscapes. 


\section{References}

Acharya KP. 2002. Twenty-four years of community forestry in Nepal. International Forestry Review 4(2):149-156.

Acharya K and Acharya S. 2007. Small-scale wood-based enterprises in community forestry: Contribution to poverty reduction. Banko Janakari 17(1):3-10.

Acharya RP. 2005. Socio-economic impacts of community based forest enterprises in mid hills of Nepal - case study from Dolakha district. Banko Janakari 15(2):43-7.

Acharya RP. 2013. A Rapid Assessment of Forest-Based Enterprises in Nepal. Kathmandu: Multi Stakeholder Forestry Programme (MSFP).

[AEC/FNCCI] Agro Enterprise Centre/Federation of Nepalese Chamber of Commerce and Industry. 2012. NTFPs/MAPs Business Promotion Strategy (2012-2016). From Private Sector Perspective. Kathmandu: Federation of Nepalese Chamber of Commerce and Industry (FNCCI).

Albano A, Pandit BH, Kumar C and Belcher B. 2008. Developing Community-Based Forest Enterprises in Nepal. Forest Livelihood Briefs no. 10. Bogor, Indonesia: CIFOR.

[ANSAB] Asia Network for Sustainable Agriculture and Bioresources. 2009. Challenges and Opportunities for Nepal's Small and Medium Forest Enterprises (SMFEs). Rome: Food and Agriculture Organization

[ANSAB] Asia Network for Sustainable Agriculture and Bioresources. 2010. Entrepreneurship Development of Natural Resources Dependent Communities. Rural Development Toolkit Series no. 1. Kathmandu: ANSAB.

Antinori C and Bray DB. 2005. Community forest enterprises as entrepreneurial firms: Economic and institutional perspectives from Mexico. World Development 33(9):1529-43.

Arnold JM and Campbell JG. 1986. Collective management of hill forests in Nepal: The community forestry development project. In Proceedings of the Conference on Common Property Resource Management 425:464.

Badini OS, Hajjar R and Kozak R. 2018. Critical success factors for small and medium forest enterprises: A review. Forest Policy and Economics 94:35-45.

Banjade MR and Paudel NS. 2008. Economic potential of non-timber forest products in Nepal: Myth or reality? Journal of Forest and Livelihood 7(1): 36-48.

Baral S, Khanal R, Malla Y, Bolin A, Buffle Y, Pathak B and Poudel J. 2016. Increasing Private Sector Involvement and Investment in Forestry in Nepal. Briefing. London: International Institute for Environment and Development.

Baynes J, Herbohn J, Smith C, Fisher R and Bray D. 2015. Key factors which influence the success of community forestry in developing countries. Global Environmental Change 35:226-38.

Berkes F and Davidson-Hunt IJ. 2010. Innovating through commons use community-based enterprises. International Journal of the Commons 4(1):1-7.

Bolin A. 2018. Transforming Gender Relations: Upscaling Collective Action in Women's Entrepreneurship. Briefing. London: International Institute for Environment and Development.

Bolin A, Macqueen D and Harty E, eds. 2017. Risk management for locally controlled business: Securing the future. Proceedings of the Fifth International Forest Connect workshop. Quito, Ecuador, 22-24 October 2016. London: International Institute for Environment and Development.

Bray D. 2010. Toward 'post-REDD+Landscapes'. Mexico's Community Forest Enterprises Provide a Proven Pathway to Reduce Emissions from Deforestation and Forest Degradation. Infobrief no. 30. Bogor, Indonesia: CIFOR.

[CBS and UNFPA] Central Bureau of Statistics and New York: United Nations Population Fund. 2014. Population Monograph of Nepal 2014. Volume 1: Demographic Analysis. Kathmandu: Central Bureau of Statistics and New York: United Nations Population Fund.

Dhakal SR, Sharma AR and Paudel G. 2018. Investments and benefits associated with community based forest enterprises in Nepal. Banko Janakari 28(2):52-9. 
Donovan J, Stoian D, Macqueen D and Grouwels S. 2006. The Business Side of Sustainable Forest Management: Small and Medium Forest Enterprise Development for Poverty Reduction. Natural Resource Perspectives 104. London: Overseas Development Institute.

Edwards DM. 1996. The trade in non-timber forest products from Nepal. Mountain Research and Development 16(4):383-94.

Elson D. 2012. Guide to Investing in Locally Controlled Forestry. Growing Forest Partnerships in association with FAO, IIED, IUCN, The Forest Dialogue, and the World Bank. London: IIED.

[FAO] Food and Agriculture Organization. 2005. Microfinance and Forest-based Small-scale Enterprises. FAO Forestry Paper no. 146. Rome: Food and Agriculture Organization.

[FAO] Food and Agriculture Organization. 2009. Challenges and Opportunities for Nepal's Small and Medium Forest Enterprises. Rome: Food and Agriculture Organization.

Fox J. 1993. Forest resources in a Nepali village in the 1980s and 1990s: The positive influence of population growth. Mountain Research \& Development 13(1):89.

Gauli K and Hauser M. 2009. Pro-poor commercial management of non-timber forest products in Nepal's community forestry user groups: Factors for success. Mountain Research and Development 29(4):298-307.

[GoN] Government of Nepal. 2014. Nepal Gazette: Part 64, Volume 20, Section 5, dated 22 Sep, 2014. Department of Printing, Ministry of Information and Communication, Government of Nepal.

[GoN] Government of Nepal. 2016. Labour Migration for Employment( A Status Report for Nepal 2014/15). Kathmandu: Ministry of Labour and Employment, Government of Nepal.

Greene S. 2015. A Short Guide to Impact Investing. Washington, DC: The Case Foundation.

Gynch S, Lawry S, Monterrosa I, Adhikary A and McLain R. 2019. A Guide to Investing in Collectively Held Resources. Bogor, Indonesia: CIFOR.

[HMG/MoLJ] His Majesty Government of Nepal/Ministry of Law and Justice. 1993. Forest Act, 1993. Kathmandu: His Majesty Government of Nepal/Ministry of Law and Justice.

Hobley M and associates. 2015. Persistence and Change: Review of 30 years of Community Forestry in Nepal. Kathmandu: Multi Stakeholder Forestry Programme (MSFP).

Jhaveri N and Adhikari J. 2016. Nepal Land and Resource Tenure Assessment for Proposed Emission Reductions Program in the Terai Arc Landscape. Washington, DC: USAID Tenure and Global Climate Change Program.

Kanel K. 2000. Analysing policy for poverty alleviation: An example from non-timber forest product subsector. Banko Janakari 10(2):3-8.

Kanel KR and Niraula DR. 2017. Can rural livelihood be improved in Nepal through community forestry? Banko Janakari 14(1):19-26.

Khanal R and Bhujei KB. 2008. NTFPs/MAPS management's contribution to livelihood improvement of the rural poor and lessons learned from the Churia Programme: The experience of CARE Nepal. In The International Union for the Conservation of Nature. International Conference Proceedings: The Role of NTFPs in Poverty Alleviation and Biodiversity Conservation. Hanoi: IUCN. 48-51.

Kunwar SC, Ansari AS and Luintel H. 2009. Non-timber Forest Products Enterprise Development: Regulatory Challenges Experienced in the Koshi Hills. ForestAction Discussion Paper. Kathmandu: ForestAction.

Lamsal P, Pant KP and Bhatta DR. 2017. Forest-based micro and small enterprises in Nepal: Review of status, constraints, scope, and approach effectiveness. International Forestry Review 19(1): 42-54.

Larsen HO, Olsen CS and Boon TE. 2000. The non-timber forest policy process in Nepal: Actors, objectives and power. Forest Policy and Economics 1:267-81.

Macqueen D. 2008. Supporting Small Forest Enterprises: A Cross-Sectoral Review of Best Practice. IIED Small and Medium Forestry Enterprise Series no. 23. London: IIED.

Macqueen D. 2019. Forest Business Incubation: The Heartbeat of Healthy Landscape Livelihoods. London: IIED.

Macqueen D, Ed., with Andaya E, Begaa S, Bringa M, Greijmans M, Hill T, Humphries S, Kabore B, Ledecq T, Lissendja T et al. 2014. Prioritising Support for Locally Controlled Forest Enterprises. London: IIED. 
Macqueen D, Benni N, Boscolo M and Zapata J. 2018a. Access to Finance for Forest and Farm Producer Organizations (FFPOS). Rome and London: FAO and IIED.

Macqueen D and Bolin A, eds. 2018. Forest Business Incubation: Towards Sustainable Forest and Farm Producer Organization (FFPO) Businesses that Ensure Climate Resilient Landscapes. Rome and London: FAO and IIED.

Macqueen D, Bolin A, Greijmans M, Grouwels S and Humphries S. 2018b. Innovations towards prosperity in locally controlled forestry models and prospects for scaling up. World Development https://doi.org/10.1016/j.worlddev.2018.08.004

Mayers J, Buckley J and Macqueen D. 2016. Small, but Many, is Big: Challenges in Assessing the Collective Scale of Locally Controlled Forest Linked Production and Investment. Issue Paper. London: IIED.

[MEDEP] Micro-Enterprise Development Program. 2010. Impact Assessment of Micro-Enterprise Development Program. Kathmandu: Micro-Enterprise Development Program.

[MEDEP] Micro-Enterprise Development Program. 2011. Value Chain Based Approach to MicroEnterprise Development Chyuri Herbal Soap Value Chain. Kathmandu: Micro-Enterprise Development Program.

[MEDEP] Micro-Enterprise Development Program. 2013. An Assessment of Potentials and Constraints of Timber Enterprise in Community Forestry Users Groups: A Case Study of Shreechhap Deorali Community Forestry Users' Group in Sindhupalchok District. Kathmandu: Micro-Enterprise Development Program.

Ministry of Commerce. 2016a. National Trade Integration Strategy. Executive Summary and Action Matrix. Kathmandu: Ministry of Commerce, Government of Nepal.

Ministry of Commerce. 2016b. National Trade Integration Strategy. Addressing the Needs of Wmen SMSEs. Kathmandu: Ministry of Commerce, Government of Nepal.

Molnar A, Liddle M, Bracer C, Khari A, White A and Bull J. 2007. Community-based Forest Enterprises in Tropical Forest Countries: Status and Potential. Yokohama: International Tropical Timber Organization, and Washington, DC: Rights and Resources Initiative.

Ojha H. 2000. Current Policy Issues in NTFP Development in Nepal. Kathmandu: Asia Network for Small-scale Bioresources (ANSAB).

Pasiecznik N, Savenijie H, Campbell J and Macqueen D. 2015. What makes producer organizations effective? In Pasiecznik N and Savenijie H. 2015. Effective Forest and Farm Producer Organizations. Wageningen, The Netherlands: Tropenbos International. 3-20.

Paudel G. 2018. Where are We Investing for NTFP Development in Nepal? Presented at conference on "Wild harvests, governance, and livelihoods in Asia" held from 30 November to 2 December 2017.

Paudel NS, Adhikary A, Mbairamadji J and Nguyen TQ. 2018. Small-scale Forest Enterprise Development in Nepal: Overview, Issues and Challenges. Rome: FAO.

Paudel NS, Budhathoki P and Sharma UR. 2007. Buffer zones: new frontiers for participatory conservation? Journal of Forest and Livelihood 6(2):44-53.

Paudel NS, Ohja H, Shrestha K, Cedamon E, Karki R, Paudel G, Basyal M, Nuberg I and Dangal S. 2019. Towards active utilization of community forestry: Silvo-institutional model for sustainable forest management in Nepal. Banko Janakari Special Issue no. 4:120-9.

Pokharel B, Poudel D, Branney P, Khatri DB and Nurse M. 2006. Reconstructing the concept of forest-based enterprise development in Nepal: Towards a Pro Poor Approach. Journal of Forest and Livelihood 5(1):53-65.

Pyakurel D and Baniya A. 2011. NTFPs: Impetus for Conservation and Livelihood support in Nepal. A Reference Book on Ecology, Conservation, Product Development and Economic Analysis of Selected NTFPs of Langtang Area in the Sacred Himalayan Landscape. Kathmandu: WWF Nepal.

PROFOR. 2018. Unlocking the Potential of Forest Enterprises: Small and Medium Enterprises. Washington, DC: PROFOR.

Rai J, Paudel RP and Pathak R. 2016. Promoting Forest-Based Enterprises in Nepal: Lessons from Piloting Activities in Koshi Hill Districts. Kathmandu: ForestAction Nepal.

Regmi MC. 1984. The State and Economic Surplus: Production, Trade, and Resource-Mobilization in Early 19th Century Nepal. Varanasi, India: Nath Publishing House. 
Rytkönen A. 2016. Forest-based Value Chains in Nepal. MSFP Working Paper. Kathmandu: MultiStakeholder Forestry Programme.

Sharma P and Shrestha N. 2011. Promoting Exports of Medicinal and Aromatic Plants (MAPS) and Essential Oils from Nepal. Kathmandu: South Asia Watch on Trade, Economics and Environment (SAWTEE).

Sharma BP, Lawry S, Paudel NS, Adhikary A and Banjade MR. 2017. Has Devolution of Forest Rights in Nepal Enabled Investment in Locally Controlled Forest Enterprises? Paper presented at the Annual World Bank Conference on Land and Poverty from March 20-24, 2017. https://www. cifor.org/wp-content/uploads/sites/worldbank2017/Sharma_364.pdf

Sharma BP, Lawry S, Paudel NS, Mclain R, Adhikary A and Banjade MR. In press. Operationalizing a framework for assessing the enabling environment for community forest enterprises: A case study from Nepal. Small-Scale Forestry

Shrestha NK and Britt C. 1998. From Pilot to Policy: Community Forestry Comes of Age in Nepal. Washington, DC: The World Bank/WBI's CBNRM Initiative.

Stoian D, Donovan J and Poole N. 2009. Unlocking the Development Potential of Community Forest Enterprises: Findings from a Comparative Study in Asia, Africa, Latin America and the United States. Presented at the XIII World Forestry Congress in Buenos Aires, Argentina, 18-23 October 2009.

Subedi B. 1999. Non-timber Forest Products sub-Sector in Nepal. Opportunities and Challenges for Linking the Business with Biodiversity Conservation. Presented at a workshop on Natural Resource Management for Enterprise Development in the Himalayas, August 19-21, 1999, Nainital, India.

Subedi B. 2006. Small, low intensity, and community forests. Case studies. London: Forest Stewardship Council.

Subedi BP, Ghimire PL, Koontz A, Khanal SC, Katwal P, Sthapit KR and Mishra SK. 2014. Private Sector Involvement and Investment in Nepal's Forestry: Status, Prospects, and Ways Forward. Study report. Kathmandu: Multi Stakeholder Forestry Programme (MSFP).

Subedi BP, Nicholson K, Ojha HR and Binayee SB. 2002. Community-Based Forest Enterprises in Nepal: Case Studies, Lessons and Implication. Kathmandu: ANSAB and SNV/Nepal.

Thing SJ and Poudel B 2017. Buffer zone community forestry in Nepal: Examining tenure and management outcomes. Journal of Forest and Livelihood 15(1):57-70.

Timsina NP 2005. Supporting Livelihoods through Employment: The Chaubas Bhumlu Community Sawmill, Nepal. Yokohama, Washington, DC, Bangkok, Washington, DC: ITTO, Forest Trends, RECOFTC, Rights and Resources Initiative.

Tirivayi N, Nennen L, Tesfaye W and Ma Q. 2018. The benefits of collective action: Exploring the role of forest producer organizations in social protection. Forest Policy and Economics 90:106-114.

Verdone M. 2018. The World's Largest Private Sector: Recognizing the Cumulative Economic Value of Small-Scale Forest and Farm Producers. Gland, Rome, London, Paris: IUCN, FAO, IIED, Agricord. 



\section{DOI: $10.17528 /$ cifor/007445}

CIFOR Working Papers contain preliminary or advance research results on tropical forest issues that need to be published in a timely manner to inform and promote discussion. This content has been internally reviewed but has not undergone external peer review.

Forest rights devolution in Nepal from the late 1980s created different types of community-based forest management institutions, in particular community forestry user groups. Effective forest regeneration led to a new focus on entrepreneurial opportunities for improving livelihoods and social equity, resulting in considerable if unstable enterprise growth. Employing the concept of enabling and asset investments, the study examines how user groups have established and managed forest-based enterprises, taking account of regulatory and non-regulatory factors. The study is based on primary data from interviews with 12 community-managed forest enterprises as well as secondary data from the published, government and grey literature. In light of the high export demand for non-timber forest products from India and elsewhere, there has been gradual policy support for enterprise development from the government. Enabling investments by the government, donors and nongovernmental organizations have built momentum and contributed to success. Forest-based enterprises have the potential to change the face of Nepal's rural economy. However, complex and poorly harmonized regulatory requirements have kept many community-managed forest enterprises in a state of informality and unable to attract asset investment. An emerging second generation of community-managed forest enterprises can benefit from reductions in regulatory burdens and attract asset investments capable of overcoming current obstacles to growth.

The CGIAR Research Program on Policies, Institutions, and Markets (PIM) leads action-oriented research to equip decisionmakers with the evidence required to develop food and agricultural policies that better serve the interests of poor producers and consumers, both men and women. PIM combines the resources of CGIAR centers and numerous international, regional, and national partners. The program is led by the International Food Policy Research Institute (IFPRI). www.pim.cgiar.org

\section{cifor.org | forestsnews.cifor.org}

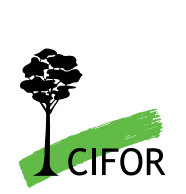

Center for International Forestry Research (CIFOR)

CIFOR advances human well-being, equity and environmental integrity by conducting innovative research, developing partners' capacity, and actively engaging in dialogue with all stakeholders to inform policies and practices that affect forests and people. CIFOR is a CGIAR Research Center, and leads the CGIAR Research Program on Forests, Trees and Agroforestry (FTA). Our headquarters are in Bogor, Indonesia, with offices in Nairobi, Kenya; Yaounde, Cameroon; Lima, Peru and Bonn, Germany.

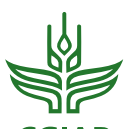

